\title{
Seasonal abundance and feeding patterns of copepods Temora longicornis, Centropages hamatus and Acartia spp. in the White Sea $\left(66^{\circ} \mathrm{N}\right)$
}

\author{
Daria M. Martynova • Natalia A. Kazus • \\ Ulrich V. Bathmann • Martin Graeve • \\ Alexey A. Sukhotin
}

Received: 8 September 2010/Revised: 15 February 2011/Accepted: 16 February 2011/Published online: 13 March 2011

(C) Springer-Verlag 2011

\begin{abstract}
We have studied the seasonal dynamics of abundance and feeding characteristics of three species of calanoid copepods (Acartia spp., Centropages hamatus and Temora longicornis) in the White Sea from the surface water layer $(0-10 \mathrm{~m})$, in order to assess their role in the pelagic food web and to determine the major factors governing their population dynamics during the productive season. These species dominated in the upper water layer (0-10 m) from June through September, producing up to 3 generations per year. Data on the food spectra revealed all species to be omnivorous; but some inter- and intraspecific differences were observed. Generally, copepods consumed diatoms, dinoflagellates and microzooplankton. The omnivory index 'UC' (i.e., fatty acid unsaturation coefficient) varied from 0.2 to 0.6 , which implied ingestion of phytoplankton. The different degree of selectivity on the same food items by the studied species was observed, and therefore, successful surviving strategy with minimal overlapping could be assumed. In total, the populations of the three studied copepod species grazed up to $2.15 \mathrm{~g}$ $\mathrm{C} \mathrm{m}^{-2}$ day $^{-1}$ and released up to $0.68 \mathrm{~g} \mathrm{C} \mathrm{m}^{-2}$ day $^{-1}$ in faecal pellets. They consumed up to $50 \%$ of particulate organic carbon, or up to $85 \%$ of phytoplankton standing
\end{abstract}

D. M. Martynova $(\bowtie) \cdot$ A. A. Sukhotin

White Sea Biological Station, Zoological Institute of Russian

Academy of Sciences, Universitetskaya nab., 1,

199034 St. Petersburg, Russia

e-mail: daria.martynova@gmail.com

\section{N. A. Kazus}

P.P. Shirshov Institute of Oceanology, Atlantic Branch, Mira pr., 1, 236000 Kaliningrad City, Russia

U. V. Bathmann · M. Graeve

Alfred-Wegener-Institut für Polar und Meeresforschung,

Am Handelshafen 12, 27570 Bremerhaven, Germany stock (in terms of Chl. a), and thus played a significant role in the transformation of particulate organic matter. Seasonal changes in abundance of the studied species depended mostly on water temperature in the early summer, but were also affected by food availability (Chl. $a$ concentration) during the productive season.

Keywords Acartia - Temora - Centropages - Feeding · Population dynamics . The White Sea - Zooplankton

\section{Introduction}

Copepods play a key role in marine pelagic food webs, transferring organic matter produced by unicellular algae and microzooplankton to higher trophic levels such as pelagic fish. Grazing by copepods largely determines the amount and composition of vertical particle flux, when copepods produce significant amount of faecal pellets, which sink to the bottom and re-mineralize in the water column (Olli et al. 2007). Two major groups of factors that govern the reproduction and thus population dynamics of predominantly herbivorous copepods in high-Arctic regions are defined. First group includes factors that govern the food limitation, i.e. light intensity and nutrient concentration affecting the phytoplankton production, while the water temperature may impact to a vertical distribution of the species through the year (Carmack and Wassmann 2006). A pronounced seasonal variation of primary production is the major typical characteristic of the Arctic seas (Mousseau et al. 2001). Feeding activity of herbivorous zooplankton and the peak of vertical organic matter flux are closely related to phytoplankton blooms (Hagen 1999; Carmack and Wassmann 2006).

The White Sea (Fig. 1) is situated in the sub-Arctic and has well-expressed seasonality (Berger et al. 2001) with the 
late spring being one of the most productive seasons in the pelagic zone. The White Sea system shows the characteristics of high-Arctic areas during both the hydrological winter (ice coverage season) and spring, while in summer it can be characterized as a temperate sea, including peculiarities of the water temperature and zooplankton community structure in the upper water layer $0-10 \mathrm{~m}$ (Prygunkova 1974; Berger et al. 2001; Pertsova and Kosobokova 2003; present study). As a rule, surface waters in spring time are occupied by cold-water copepod species such as Calanus glacialis and Pseudocalanus spp., while during the summer period, these species are replaced by boreal 'warm-water' copepods, i.e. Acartia, Temora and Centropages genera. In contrast to the high Arctic, the White Sea also has a distinct second peak of primary production in July-August due to both pronounced solar summer intensity and relatively high nutrient availability (Berger et al. 2001). It is still unknown how this vast stock of organic matter, including microzooplankton, is utilized in the marine ecosystem. We hypothesize that the major consumers in summer are the boreal copepods, as they dominate the summer zooplankton communities (Prygunkova 1974; Martynova 2003, 2005).

Average biomass of mesozooplankton in the White Sea is about $200 \mathrm{mg} \mathrm{m}^{-3}$, which is comparable to that in other seas, with peak values as high as $2.500 \mathrm{mg} \mathrm{m}^{-3}$ (Berger et al. 2003). Copepods may constitute up to $90 \%$ of mesozooplankton in terms of abundance and more than $95 \%$ by biomass (Berger et al. 2001), with calanoids being a predominant group. In the White Sea, changes in zooplankton community, including dynamics of the species abundance and the disappearance of the warm-water species in the winter period, are pronounced in the upper layers through the ice-free season (Prygunkova 1974; Pertsova and Kosobokova 2003). Key calanoid species inhabiting the White Sea can be separated into two large groups of species according to their temperature and depth preferences. Coldwater calanoids (Calanus glacialis, Metridia longa, Pseudocalanus spp.) are present all the year round as copepodites in different developmental stages; Calanus and Pseudocalanus feed actively in spring (March-May) in the upper water layers and migrate to water layers below the thermocline in summer (Kosobokova 1999; Pertsova and Kosobokova 2003). In contrast, 'warm-water' calanoid species Acartia spp. (A. longiremis and A. bifilosa), Centropages hamatus, Temora longicornis appear in the upper water layers $(0-30 \mathrm{~m})$ only during warm periods (water temperatures above $8^{\circ} \mathrm{C}$ ), i.e. from June to September, while hibernating as dormant eggs in winter (Prygunkova 1974; Usov and Zubakha 2004). These species can dwell down to $30 \mathrm{~m}$ depth; however, $90 \%$ of their population remains in the thin surface water layer of $0-10 \mathrm{~m}$ (Berger et al. 2001, 2003 original data, unpublished). These copepods do perform diel vertical migrations, but only within the upper $0-30 \mathrm{~m}$ water layer (Martynova and Vakatov, unpublished data). Apparently, these species contribute significantly to the ecosystem, but virtually nothing is known about their food spectra, grazing and clearance rates. These data are important towards an understanding of their role in sub-Arctic seas, such as the White Sea.

The other important question addressed in the present study was to determine the major factors governing the population dynamics of the boreal copepods in the subArctic sea. Previous research (Prygunkova 1974; Berger et al. 2001, 2003) considered low water temperatures as a limiting factor for the population of these warm-water
Fig. 1 Map of the sampling area (the White Sea, Russian sub-Arctic). D-1, K, 1-6-stations

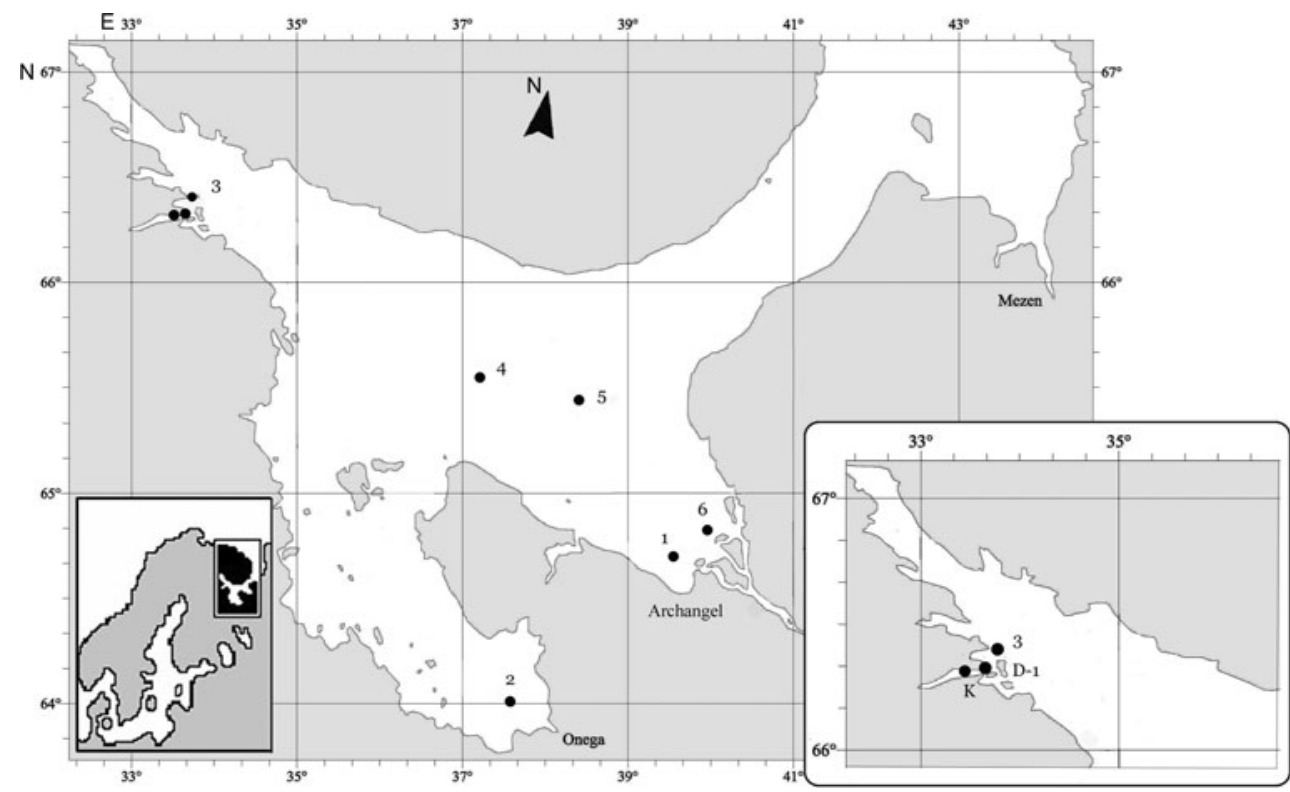


copepods. However, studies in the Baltic and the North seas clearly showed successful wintering of these species as copepodites even when the water temperatures were close to zero. Their survival was mostly dependent on the food supply (Devreker et al. 2005; Wesche et al. 2007)

This is the first study that links population dynamics of the boreal copepod species in the White Sea and the major environmental factors affecting their abundance. Seasonal changes of zooplankton abundance were studied at the two nearshore stations, and geographical variation was explored during a cruise in early July. Feeding characteristics such as food spectra of copepods and their feeding and faecal pellet production rates were studied experimentally in order to assess grazing impact of these species in the $0-10 \mathrm{~m}$ layer, where their abundance is maximal. Finally, the influence of environmental factors (temperature and food availability) on the dynamics of boreal copepods in the sub-Arctic sea during the productive period was analysed.

\section{Materials and methods}

Zooplankton and seston sampling

The abundance of Acartia spp. (A. longiremis and A. bifilosa), Centropages hamatus and Temora longicornis was estimated in different parts of the White Sea during the summer season of 2002 (Fig. 1; Table 1). All zooplankton samples were taken in series of vertical tows from 0 to $10 \mathrm{~m}$ with a Juday net $(100-\mu \mathrm{m}$ mesh gauze and $37 \mathrm{~cm}$ diameter) by standard techniques (Harris et al. 2000). In the White Sea, $90 \%$ of the warm-water copepod population (in terms of both abundance and biomass) are found in the surface layer of 0-10 m (Prygunkova 1974; original data). The samples were fixed with $\mathrm{CaCl}_{2}$-buffered formaldehyde (4\% final concentration) (Harris et al. 2000). At station K and stations $1-6$, a second zooplankton sample was taken from the same water layer for live copepods, which were immediately transported to the laboratory and used for grazing experiments.

Table 1 Sampling sites

\begin{tabular}{|c|c|c|c|c|}
\hline Station & Area & Coordinates & Bottom depth, $m$ & Sampling date \\
\hline D-1 & Kandalaksha Bay, Cape Kartesh & $66^{\circ} 20.2^{\prime} \mathrm{N}, 33^{\circ} 38.9^{\prime} \mathrm{E}$ & 63 & $\begin{array}{l}14.05 .02 \\
01.06 .02 \\
11.06 .02 \\
20.06 .02 \\
10.07 .02 \\
20.07 .02 \\
30.07 .02 \\
10.08 .02 \\
20.08 .02 \\
31.08 .02 \\
10.09 .02\end{array}$ \\
\hline $\mathrm{K}$ & Kandalaksha Bay, Kruglaya Inlet & $66^{\circ} 20.2^{\prime} \mathrm{N}, 33^{\circ} 38.8^{\prime} \mathrm{E}$ & 15 & $\begin{array}{l}22.05 .02 \\
05.06 .02 \\
14.06 .02 \\
25.06 .02 \\
11.07 .02 \\
21.07 .02 \\
31.07 .02 \\
11.08 .02 \\
21.08 .02 \\
31.08 .02 \\
11.09 .02\end{array}$ \\
\hline 1 & Dvina Bay, near Severodvinsk & $64^{\circ} 45.2^{\prime} \mathrm{N}, 39^{\circ} 30.7^{\prime} \mathrm{E}$ & 15 & 27.06 .02 \\
\hline 2 & Onega Bay, innermost part & $64^{\circ} 09.2^{\prime} \mathrm{N}, 37^{\circ} 19.7^{\prime} \mathrm{E}$ & 35 & 28.06 .02 \\
\hline 3 & Kandalaksha Bay, Sidorov Island & $66^{\circ} 07.0^{\prime} \mathrm{N}, 34^{\circ} 24.3^{\prime} \mathrm{E}$ & 39 & 01.07 .02 \\
\hline 4 & Central part (Basin) & $65^{\circ} 36.5^{\prime} \mathrm{N}, 37^{\circ} 14.6^{\prime} \mathrm{E}$ & 165 & 03.07 .02 \\
\hline 5 & Central part (Basin) & $65^{\circ} 26.1^{\prime} \mathrm{N}, 38^{\circ} 40.3^{\prime} \mathrm{E}$ & 105 & 04.07 .02 \\
\hline 6 & Dvina Bay, Mudjug Island & $64^{\circ} 49.0^{\prime} \mathrm{N}, 40^{\circ} 00.5^{\prime} \mathrm{E}$ & 13 & 06.07 .02 \\
\hline
\end{tabular}


Seasonal variation of copepod abundance was studied at stations D-1 and K during May-September, 2002. At Station D-1 (63 $\mathrm{m}$ depth), sampling was performed every 7-10 days between 10 and 12 a.m. At Station K (15 m depth), samples were also taken every 7-10 days. Possible diurnal fluctuations in zooplankton community in a shallow bay (Station $\mathrm{K}$ ) were assessed by means of sampling every 2-3 h through 24-h period. All the samples were analysed individually, and, where applicable, the average copepod abundance was calculated. Temperature and salinity were measured simultaneously with the zooplankton sampling throughout the 0-10 $\mathrm{m}$ water layer by means of MIDAS CTD, and the data for 0,5 and $10 \mathrm{~m}$ depths were included in the analysis.

Seston samples were taken using $5 \mathrm{~L}$ Niskin bottles at 0 and $5 \mathrm{~m}$ depths to study the phytoplankton and microzooplankton abundance, particulate organic carbon (POC) and Chl. $a$ concentration. The samples were immediately mixed to analyse the 'overall' pattern of the food environment.

Experiments on grazing and faecal pellet production rates

From June through September 2002, grazing and pellet production was measured at Station K. These were also measured during the 52nd cruise of RV 'Ivan Petrov' at sampling stations 1-6 (Fig. 1; Table 1) for comparison with other regions of the White Sea. Water for the experiments was collected with 5-L Niskin bottles at 0 and $5 \mathrm{~m}$ depths; these samples were mixed in equal volumes to simulate the natural seston mixture in the upper water layer. Water samples were filtered through 100- $\mu \mathrm{m}$ mesh gauze and analysed for particulate organic matter (POM) concentration. This water was also used as a food source in the grazing experiments. This filtering excluded numerous small copepods, which may graze on POM and add extra pellets to the experimental bottle or re-ingest copepod pellets (Svensen and Nejsgaard 2003), and some large and colonial diatoms, which are usually not consumed by the species under study (preliminary original data on the food spectra). On the other hand, the pre-screening procedure may reduce the number of large naked protists and thus affect the food spectra. However, excluding the prescreening procedure increases the number of small zooplankters, which may have more grazing effect and thus lead to overestimation of the copepod grazing rates (Gifford et al. 1995). The potentially high grazing impact of microzooplankton smaller than $200 \mu \mathrm{m}$ was minimized by using fine mesh of $100 \mu \mathrm{m}$ for pre-screening, and the small remaining effect was corrected for by using bottles without copepods as controls. Before the experiment, three $500 \mathrm{~mL}$ portions of pre-screened water were filtered under
0.30-0.35 Pa through a pre-weighed and pre-combusted $\left(220^{\circ} \mathrm{C}, 24 \mathrm{~h}\right) \mathrm{GF} / \mathrm{C}$ filter and then dried to constant weight at $50^{\circ} \mathrm{C}$ for $24 \mathrm{~h}$ for subsequent analysis of organic $\mathrm{C}$ and N. GF/C filters are suitable for such studies as they retain most of the particles larger than $2 \mu \mathrm{m}$. This is sufficient to study the feeding characteristics of certain zooplankton species, which consume particles of more than $5 \mu \mathrm{m}$ diameter (Berggreen et al. 1988). Another three $500 \mathrm{~mL}$ portions were filtered in the same manner and placed in 90\% acetone for further Chl. $a$ and phaeophytine (phytopigments) analysis (Bathmann and Liebezeit 1986; Evans et al. 1987). One hundred millilitres of water was fixed by standard fixatives, i.e. buffered formaldehyde solution (Harris et al. 2000) for further phytoplankton and microzooplankton analysis (Utermöhl 1958).

Prior to the experiment, the specimens of Acartia, Centropages and Temora at different developmental stages and with full guts were sorted under a dissecting microscope $(10 \times$ magnification) into three age groups accordingly to the number of pleopods and abdominal segments: young copepodites (CII-CIII), elder copepodites (CIV$\mathrm{CV}$ ) and females (CVI). Males were not studied due to their low numbers (6-9 times less abundant than females). Copepods were transferred to $100 \mathrm{~mL}$ jars (5-10 specimens per jar) containing filtered $(100 \mu \mathrm{m})$ seawater and then acclimated for $24 \mathrm{~h}$ in darkness at the temperature observed at $5 \mathrm{~m}$ depth at the time of sampling. All experiments were performed at this temperature.

For each experiment, 50 females or 100 young copepodites $(0.1-1.1 \mathrm{~mm}$ prosome length) were placed in 5.0-L transparent polycarbonate bottles filled with filtered $(100 \mu \mathrm{m})$ seawater to achieve a density of one organism or less per $50 \mathrm{~mL}$. Four to six experimental and 1-2 control (without animals) bottles were used for each experiment (Harris et al. 2000). Bottles were exposed in situ in the White Sea near the Cape Kartesh at a $5 \mathrm{~m}$ depth for 24-26 $\mathrm{h}$ by hanging them on a $5 \mathrm{~m}$ rope fixed to a standing buoy. During the cruise, bottles were rotated (ca. $20 \mathrm{rpm}$ ) in a dark sink and constantly cooled with surface water. In total, 17 experiments were performed.

At the end of each experiment, bottles were kept stationary for $15-17 \mathrm{~min}$ to let the faecal pellets sink to the bottom. Animals and faeces were gently removed with a Pasteur pipette under the microscope $(10 \times)$, counted and transferred separately to the GF/C filters for further analyses. Movements and gut content of copepods, visible through the transparent prosome, were checked to be sure all copepods were in good condition (Pasternak 1995). Animals and pellets on filters were gently washed with filtered seawater $(1 \mu \mathrm{m})$ and afterwards rinsed with 2-3 drops of deionized water. Organic $\mathrm{C}$ and $\mathrm{N}$ content of copepods was determined. Approximately half of the faecal pellets were counted, placed onto a GF/C filter and fixed in 
90\% acetone for phytopigment analysis as described above. Remaining pellets were counted, placed on another filter and prepared for $\mathrm{CN}$ analysis as described for POM samples. Subsequently, two 0.5-1.0-L subsamples of the water used in the experiments were filtered through 100- $\mu \mathrm{m}$ mesh gauze and pumped through the pre-combusted GF/C filters for subsequent analyses of organic $\mathrm{C}$ and phytopigments, and one $100 \mathrm{~mL}$ subsample was fixed for phytoplankton and microzooplankton analysis, as described above.

\section{Analytics}

Phytopigment and $\mathrm{CN}$ samples were stored with silica gel at $-23^{\circ} \mathrm{C}$ in dark hermetic containers. Phytopigment analysis was performed with Turner Designs TD-700 fluorometer using standard techniques (fluorescence before and after acidification) (Evans et al. 1987). Before CN analysis, filters were weighed to the nearest $0.05 \mathrm{mg}$ and gently washed with 3-6 drops of $1 \mathrm{~N} \mathrm{HCl}$ to remove all inorganic $C$. Then, filters were washed with $10 \mathrm{~mL}$ deionized water under $0.4 \mathrm{~Pa}$ vacuum and dried for $24 \mathrm{~h}$ to constant weight at $+54^{\circ} \mathrm{C}$. Organic $\mathrm{C}$ and $\mathrm{N}$ content were determined with a Carlo Erba NA 1500 Analyzer. One hundred to 200 animals of each species at developmental stages were taken in three replicates from the fresh sample and were used for fatty acid (FA) analysis. Copepods were gently transferred into pre-weighed cups and washed with DCM. Several blanks showed no significant deterioration of the samples. Copepods were washed with cold distilled water and then dried with Kleenex tissue. The animals were immediately preserved in dichloromethane/methanol (2:1, by vol.) and stored at $-30^{\circ} \mathrm{C}$ until analysis (FalkPetersen et al. 1987; Tande and Henderson 1988; Hagen et al. 1995). The physiological state of females was noted (ovaries presence and their ripeness, if applicable). Lipids were extracted according to Folch et al. (1957). The fatty acid and alcohol compositions were determined by gas chromatography (Kattner and Fricke 1986). Briefly, lipids were hydrolysed in methanol containing $3 \%$ concentrated sulphuric acid, and fatty acids were converted to methyl esters by transesterification at $80^{\circ} \mathrm{C}$ for $4 \mathrm{~h}$. Fatty acid methyl esters and free alcohols were simultaneously analysed with a gas liquid chromatograph (HP $6890 \mathrm{~N}$ ) on a $30 \mathrm{~m} \times 0.25 \mathrm{~mm}$ i.d. wall-coated open tubular column (film thickness: $0.25 \mu \mathrm{m}$; liquid phase: DB-FFAP) using temperature programming. Fatty acids and alcohols were identified with standard mixtures, and if necessary, additional confirmation was carried out by GC/MS. The analyses listed above were performed in the Biological Oceanography Department of the Alfred-Wegener-Institute (Bremerhaven, Germany).

Phytoplankton particles were counted for $100 \mathrm{~mL}$ sample under standard techniques (Utermöhl 1958) using DAPI as fluorescence marker. Each phytoplankton species was subdivided into one of three groups: (1) intact 'full' cells with chloroplasts; (2) intact 'empty' cells without chloroplasts; (3) broken cells. Chain-forming phytoplankton species were also treated as solitary cells and cell chains. Chaetoceros, Corethron, Thalassionema, Thalassiosira and Pseudonitzschia species were counted into three size classes: (1) cells $<50 \mu \mathrm{m}$ diameter (length); (2) cells of 50-100 $\mu \mathrm{m}$ size and (3) cells $>100 \mu \mathrm{m}$.

\section{Calculations}

The following equations were used to estimate major feeding parameters:

1. Grazing rate, GR (Frost 1972)

$$
\begin{aligned}
& \mathrm{GR}=\frac{[\mathrm{C}] \cdot V \cdot g}{N_{\mathrm{cop}}}\left(\mu \mathrm{g} \text { ind }^{-1} \mathrm{~h}^{-1}\right) \\
& {[\mathrm{C}]=\frac{q_{1 \text { experiment }} \cdot\left(e^{(k-g) \cdot t}-1\right)}{(k-g) \cdot t}} \\
& q_{2 \text { (control) }}=q_{1(\text { control })} \cdot e^{k \cdot t} \\
& q_{2 \text { (experiment) }}=q_{1 \text { (experiment) }} \cdot e^{(k-g) \cdot t}
\end{aligned}
$$

2. Faecal pellet production rate, as number of egested pellets (FPR) or organic carbon (FPC)

$$
\begin{aligned}
& \mathrm{FPR}=\frac{N_{p}}{N_{\mathrm{cop}} \cdot t}\left(\text { pellet ind }{ }^{-1} \mathrm{~h}^{-1}\right) \\
& \text { or FPC }=\frac{[\mathrm{C}]_{p} \cdot 24 h \cdot N_{p}}{N_{\text {cop }} \cdot t}\left([\mathrm{C}] \mathrm{ind}^{-1} \mathrm{day}^{-1}\right)
\end{aligned}
$$

where $[\mathrm{C}]$-POM consumed in the experimental jar

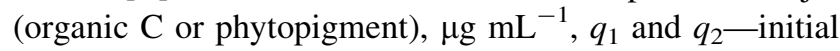
and final POM concentrations (organic $\mathrm{C}$ or phytopigment), $\mu \mathrm{g} \mathrm{mL}^{-1}, V$-volume of experimental jar, $\mathrm{mL}, t-$ duration of experiment, h, $k$-POM increasing coefficient in control jar without copepods, $\mathrm{h}^{-1}, g$-grazing (POM decreasing) coefficient in experimental bottle with copepods, $\mathrm{h}^{-1}$, coefficients $k$ and $g$ were calculated by transformation of Eqs. 1.1 and 1.2., $N_{\text {cop }}$ and $N_{p}$-numbers of copepods and pellets, respectively, in experimental jar, $[\mathrm{C}]_{p}$-organic $\mathrm{C}$ content of pellet, $\mu \mathrm{g}$.

Grazing and pellet production rates were estimated by multiplying abundance of the various stages of respective species by individual parameters of GR and FPR, expressed in organic $\mathrm{C}$. High variability in feeding activity due to the light impact was minimized in these calculations by using average values based on data of 24-h experiments from the bottles exposed at distinct depths.

Phytoplankton pigment per carbon ratio (PPC) in seston was calculated according to Harris et al. (2000). The PPC ratio means that 1 unit (i.e., $\mu \mathrm{g}$ ) of Chl. $a$ in phytoplankton refers to $n$ units of organic $\mathrm{C}$ for the same phytoplankton. 
This ratio helps to recalculate the Chl. $a$ values into the organic $\mathrm{C}$ values and is essential in assessing the role of algal food in the copepod diet, when a comparison of data of both organic $\mathrm{C}$ and Chl. $a$ has to be performed. At the beginning of the experiment, PPC averaged $120.0 \pm 59.7$, while at the end of the experiment, it was $113.2 \pm 39.2$ (control vials) and $143.6 \pm 44.7$ (experimental vials). These differences were not statistically significant; hence, we assumed a PPC ratio of 120 in our calculations. The PPC ratio was used to recalculate the amount of ingested Chl. $a$ into organic carbon and thus to estimate the percentage of algal food in the total diet.

\section{Recalculations of the species grazing effect}

To assess the role of the studied species in the ecosystem (e.g. organic carbon intake), the recalculations using original and published data were performed. Most of the suspended matter (POC) in the White Sea is concentrated in the upper water layers above the thermocline $(0-25 \mathrm{~m})$ (Berger et al. 2001; Romankevich and Vetrov 2001; Berger 2007). The Chl. $a$ maximum in the White Sea occurs in the surface water layer $(0-10 \mathrm{~m})$, throughout the productive season (Bobrov et al. 1995; Berger et al. 2001; Berger 2007). The grazing effect was estimated using previously published data on primary production (Berger 2007) and original data on Chl. $a$ and POC concentration.

\section{Statistics}

Unpaired $t$-tests were used to compare GR obtained at different stations (cruise and station $\mathrm{K}$ ) for the same age groups, CII-III, CIV (or CV) and CVI (females only) of studied species. Pearson correlation was applied to correlate species grazing impact and population abundance. Original data were $\log 10$ transformed prior to the analyses. The effects of the developmental stage and species of copepods on grazing and faecal production rates were tested with one-way repeated-measures analysis of variance (ANOVA). Linear regression analysis was used to describe plankton responses, e.g., GR of different species and developmental stages, as a function of food concentrations and to analyse interrelationships between food concentrations, zooplankton abundance and biomass and species grazing impact, the latter both in absolute and in relative units (percentage of ingested food from total potential food). To assess the influence of food quantity on the species abundance and biomass, 1-2 week shifts were applied for the data set. Linear regression analysis was also used to describe interrelationships between POM parameters and average temperature of $0-10 \mathrm{~m}$ layer. Principal component analysis was applied to FA data to reveal any differences in the relative content of major fatty acids and thus to learn more about dominant food particles ingested. $\log 10$ transformations were applied when residuals did not meet the assumptions of normality and homogeneity of variance. The analysis was performed using the Statistica 6.0 software. Mean and standard deviation $(\mathrm{m} \pm \mathrm{SD})$ are given in the text and figures.

\section{Results}

Hydrology, POC, Chl. $a$ and phytoplankton characteristics

Temperatures differed at stations D-1 and K (Fig. 2a). In general, the upper $0-10 \mathrm{~m}$ layer at Station $\mathrm{K}$ was well mixed throughout the entire period of observation, whereas significant differences within this layer were observed for Station D-1 during most of the season (Fig. 2a). The water temperature of the upper layer differed insignificantly from that of the other studied areas of the White Sea (stations 1-6) in the beginning of July (Fig. 2a). The thermocline was recorded at a depth of $20-50 \mathrm{~m}$ and was absent in shallow areas (depth $<25 \mathrm{~m}$ ) (A. Lisitzin, personal communication, data not shown).

The upper $0-5(10) \mathrm{m}$ water layer was well mixed through the summer period at both the neritic (D-1, K) and open-sea stations (1-6), and a Chl. $a$ maximum was registered in the near-surface water at depths of 5-12 m, photic layer, above the thermocline (courtesy of A. Lisitzin). Chl. $a$ concentration varied from 0.67 to $2.69 \mu \mathrm{g} \mathrm{L}^{-1}$ with variations corresponding to those observed in POC (Fig. 2b). At Station K, three pronounced peaks of POC were observed during summer of 2002 (Fig. 2c). The POC level at Station D-1 was relatively stable throughout the summer, with peaks in late spring and early autumn and decreasing to a minimum during late autumn (Fig. 2c). The absolute content of organic carbon and phytopigments in POM did not depend on the average water temperature in the $0-10 \mathrm{~m}$ layer (regression analysis, $R^{2}=0.10$; $F_{1,26}=2.9 ; \quad P=0.09 \quad$ and $\quad R^{2}=0.02 ; \quad F_{1,26}=0.4$, $P=0.51$, respectively). The $\mathrm{C}: \mathrm{N}$ ratio of $\mathrm{POM}$ ranged from 4.8 to 10.3 (7.1 on average). Secchi depths ranged from 3 to $4.5 \mathrm{~m}$; thus, the light level of $1 \%$ varied between 8.1 and $12.2 \mathrm{~m}$ (Parsons et al. 1984), so the euphotic layer did not extend deeper than $12.0 \mathrm{~m}$. The phytoplankton community in the upper $0-10 \mathrm{~m}$ was characterized by wellexpressed seasonal dynamics of the dominating species (Fig. 3a, b). In the beginning of the ice-free season (May, 22), centric diatoms (Thalassionema spp.) were the dominating group, comprised up to $86 \%$ of total phytoplankton community abundance, which reached up to $130-210$ cells $\mathrm{mL}^{-1}$ (Fig. 3a). The dinoflagellate abundance was insignificant during this period, when solitary cells were seldom 
Fig. 2 Seasonal dynamics of a temperature (average for 0-10 m); b Chl. $a$ concentration, $\mu \mathrm{g} \mathrm{L}^{-1}$ (surface); c POC concentration, $\mu \mathrm{g} \mathrm{L}^{-1}$ (surface); $\mathbf{d}$ copepod abundance, ind. $\times 10^{3} \mathrm{~m}^{-3}$ (in 0-10 m).

D-1 (black squares); $\mathrm{K}$ (empty squares), 1-6-stations (other signs)
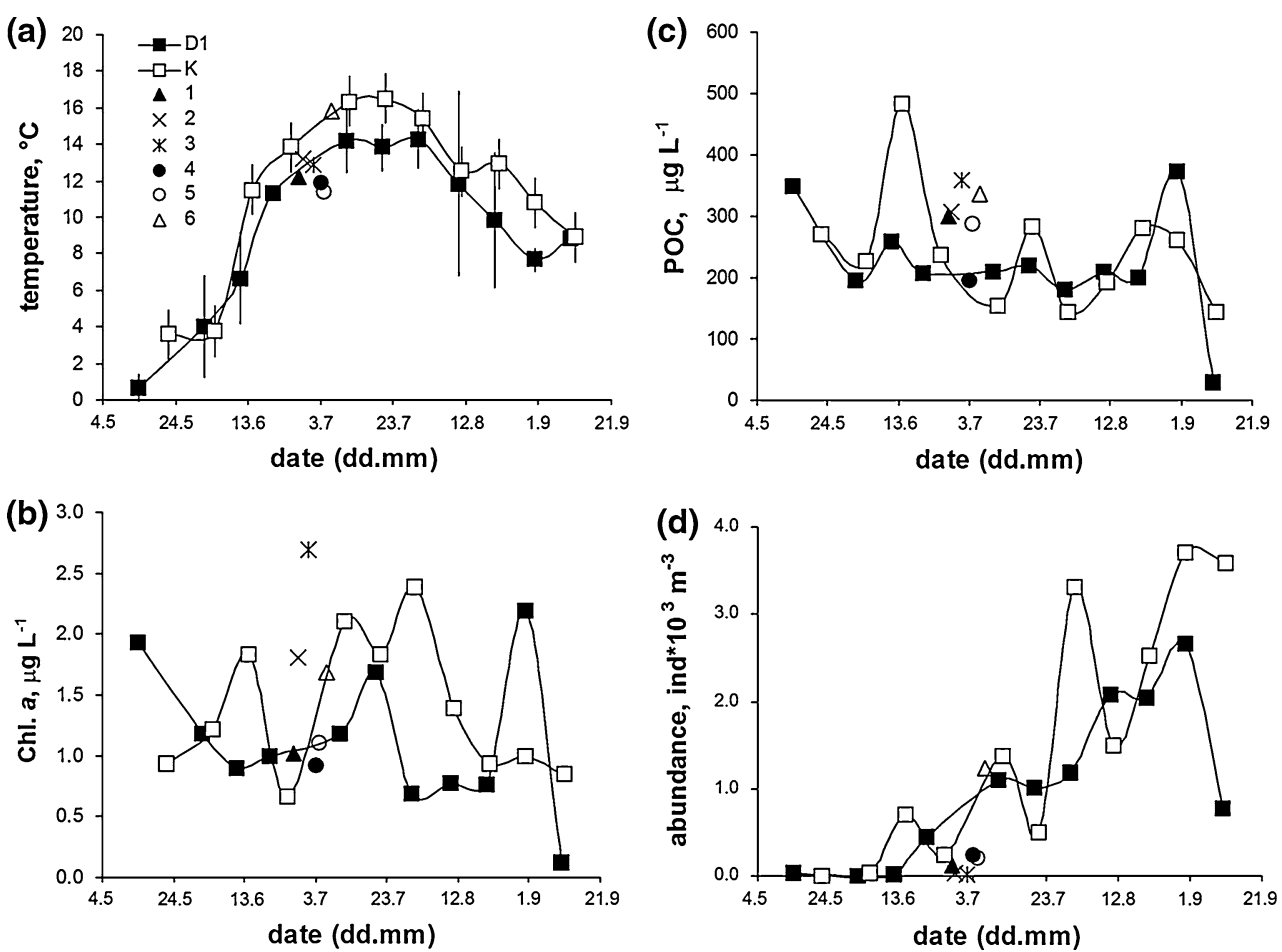

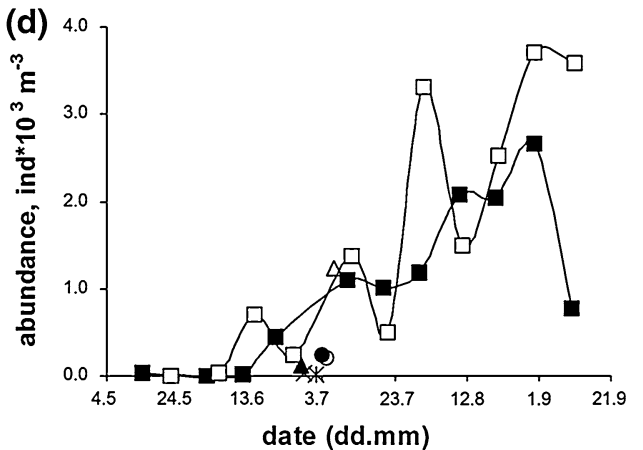

found. When the solar intensity and water temperature increased through June, the pennate diatom abundance (Chaetoceros spp., small Pseudonitzschia species) rose simultaneously; however, a dramatic decrease occurred at the end of June, which may probably be linked to both nutrient deficit and copepod grazing activity. During the second decade of July (11.07), the phytoplankton community achieved abundances of $150-250$ cells $\mathrm{mL}^{-1}$ and withheld these values for a period of over 2 months (until September, 11). However, the community pattern exhibited great changes during this period, when dominating diatoms were replaced by large dinoflagellates (Ceratium fusus, $C$. arctica), which constituted $84 \%$ of total phytoplankton abundance in the first week of September (Fig. 3b).

Utermöhl counting and fatty acid analysis results

The data on the food spectra, obtained by the Utermöhl counting method, revealed nearly all the species and developmental stages as omnivorous, consuming both phytoplankton particles and microzooplankton. In particular, only the young copepodites (CI-CIII) of Acartia fed largely on the phytoplankton, i.e. diatom species, mostly Thalassiosira, Thalassionema and Chaetoceros. The food spectra of the other developmental stages and species included also such items as small dinoflagellates and microzooplankton (protists and nauplii of other crustaceans) (Fig. 3c). There was an overlap in the food preferences of all three species, but differences were also observed among samples taken at the same date. In the beginning of the season, when Acartia dominated in the surface layers, it preferred to consume small diatoms of cell size less than $50 \mu \mathrm{m}$, which included such species as Thalassiosira, Thalassionema, Chaetoceros, Pseudonitzschia and Navicula. The same trend was observed through the season by Centropages and Temora; however, elder copepodites included some small dinoflagellates and microzooplankton in their diet. When all three species co-occurred in the surface water layer, they competed for certain food items, i.e. small diatoms of Thalassionema, Chaetoceros and Pseudonitzschia species. At the end of August, 20\% of the diet of the adults of Centropages and Temora consisted of microzooplankton. All the species and developmental stages almost totally avoided Sceletonema, Rhizosolenia and Melosira (Bacillariophytes) and nearly all the Dinophyta species, especially Ceratium. Even when the relative abundance of small diatoms was low, all the copepods were characterized by high selectivity towards these items (Fig. 3b, c). Similar FA contents were observed for the copepods of $C$. hamatus and $T$. longicornis, with similar phytoplankton biomarkers (16:2(n-4); 20:5(n-3); PUFA, UC, (n-3)/(n-6)) found for both species (Tables 2, 3; Fig. 4). The saturated (SFA) and monounsaturated (MUFA) fatty acids (14:0, 16:0, 18:0, SFA, MUFA) were observed, including copepod (18:1(n-9), 20:1(n-9)) and dinoflagellate (18:4(n-3); DHA/EPA) biomarkers, i.e. both phytoplankton/herbivorous and animal/carnivorous FA were found. There were almost no significant changes of FA relative content during the maturation, except one case, when a slight increase in 22:6(n-3) was observed in 
Fig. 3 Seasonal dynamics of phytoplankton/

microzooplankton community: a abundance, cells $\mathrm{mL}^{-1}$; b relative abundance, \%; and food items preferred by the studied species: c food spectra, $\%$; according to the Utermöhl analysis. Aca Acartia spp., Tem Temora longicornis, Cen

Centropages hamatus, $\mathrm{CI}-\mathrm{CV}$, fem copepodite stages

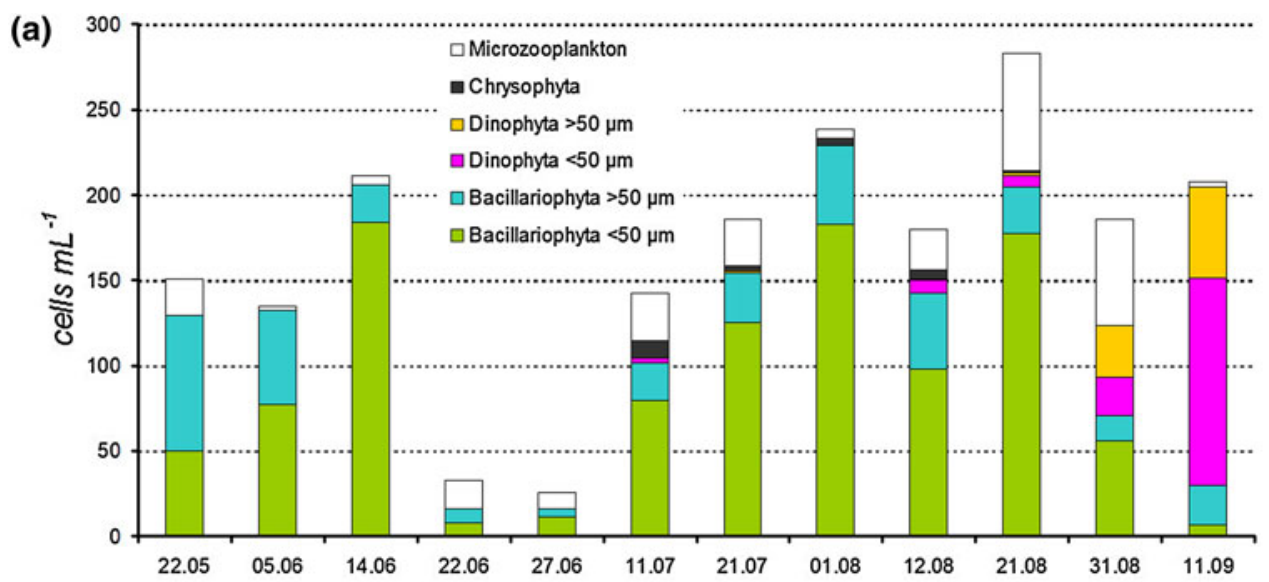

(b) $100 \%$

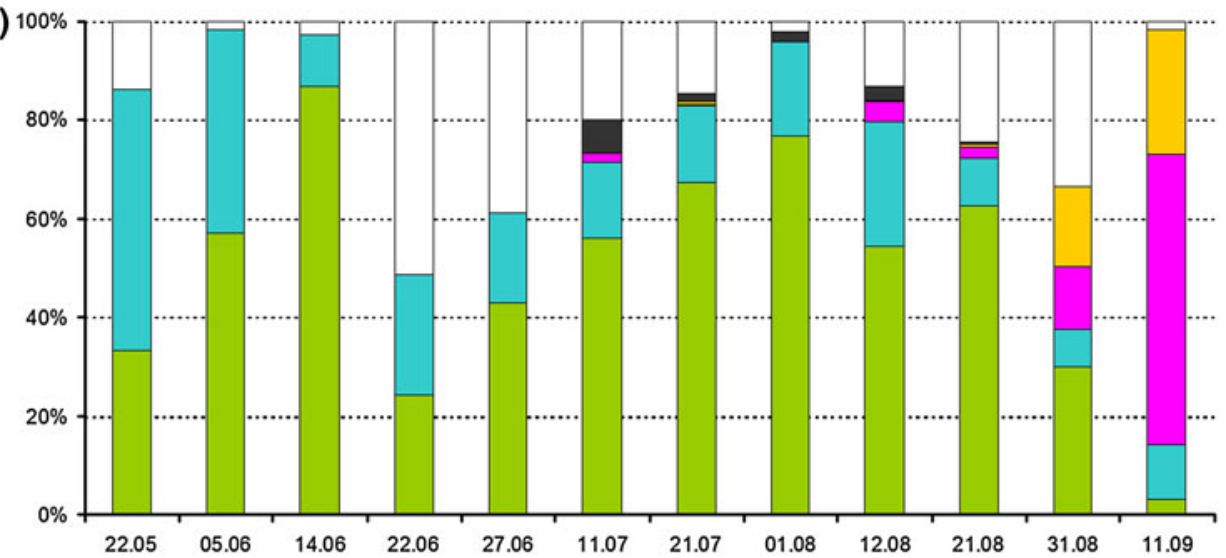

(c) 100

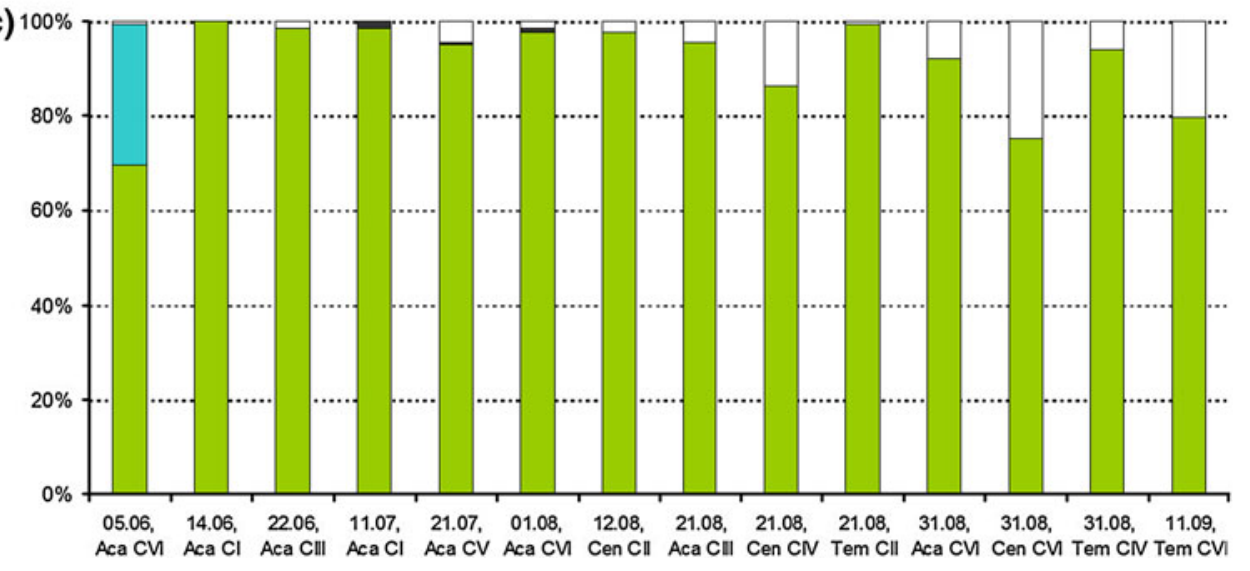

C. hamatus females. 16:1(n-7)/C16:0 ratio was the same in all the developmental stages $(0.24-0.25)$. Mature animals were characterized by a higher relative amount of 22:6(n-3); $(n-3) /(n-6)$ and nearly the same UC (i.e., fatty acid unsaturation coefficient) and 16:1/16:0 ratios than other animals. T. longicornis copepodites of different stages are quite similar to $C$. hamatus in their FA content. High content of monoenic FA 18:1(n-9) (carnivorous) was observed (Table 3). High relative contents of dinoflagellate (18:4(n-3), 22:6(n-3)) and diatom (20:5(n-3)) polyunsaturated FAs were also registered. FA content in Temora copepodites differed significantly throughout the copepod development, CVI females and CIV copepodites having similar parameters (Table 3 ). In contrast to CIV and CVI, young copepodites (CIIs) had significantly lower contents of 18:0, 18:1(n-7), 20:1(n-9), 22:5(n-3) FA and 20:1(n-9) alcohol, half as much as found in the other copepodite stages To the contrary, the contents of $16: 0,16: 1(n-7)$ and $20: 4(n-3)$ FA's were more than 2 times less than in the copepodites of other stages. We observed significant differences in FA content of $T$. longicornis and $C$. hamatus sampled two days apart (26-28.08.2002) (Tables 2, 3; Fig. 4), when females 
Table 2 Centropages hamatus

\begin{tabular}{llll}
\hline Stages & CII & CIV & Females \\
Sampling date & 12.08 .02 & 21.08 .02 & 28.08 .02 \\
\hline
\end{tabular}

Fatty acids

$14 \cdot 0$

14:1

15:0

16:0

$16: 1(\mathrm{n}-7)$

$16: 1(\mathrm{n}-5)$

$16: 2(\mathrm{n}-4)$

$16: 3(\mathrm{n}-4)$

$16: 4(\mathrm{n}-1)$

18:0

18:1(n-9)

$18: 1(\mathrm{n}-7)$

$18: 2(\mathrm{n}-6)$

$18: 3(\mathrm{n}-6)$

$18: 3(n-3)$

$18: 4(n-3)$

20:0

20:1(n-9)

$20: 1(n-7)$

20:3(n-6)

$20: 3(n-3)$

$20: 4(n-6)$

$20: 4(n-3)$

20:5(n-3)

22:5(n-3)

22:6(n-3)

Alcohols

14:0

16:0

16:1(n-7)

18:1(n-9)

18:1(n-7)

20:1(n-9)

20:1(n-7)

22:1(n-11)

SFA

MUFA

PUFA

OBFA

DHA/EPA

16:1(n-7)/16:0

(n-3)/(n-6)

$\mathrm{UC}$

DW $(\mu \mathrm{g})$

3.1
-
1.1
13.2

\section{2}

0.5

3.1

0.7

$-$

3.3

24.3

1.6

3.3

$-$

1.9

5.8

0.2

1.0

$-$

$-$$$
0.3
$$

4.1

10.9

1.8

16.1

20.9

79.1

$-$

$-$
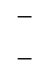

$-$

$-$

$-$

21.0

31.0

48.1

14.4

1.5

0.28

9.5

0.5

2.000
2.8

$-$

18.2

4.4

$-$

1.5

0.6

$-$

3.9

23.4

2.8

2.2

1.2

1.2

3.8

0.4

2.2

0.6

$-$

$-$

0.5

1.8

8.5

2.2

14.8

24.0

76.0

$-$

$-$

$-$

$-$

$-$

$-$

27.4

33.3

38.3

20.3

1.7

0.24

7.3

0.4

6.000

Relative FA content, \%, and main indexes, '-' FA/FAlc content is less than $0.2 \%$. SFA saturated FA, \%; MUFA monounsaturated FA, \%; PUFA polyunsaturated FA, \%; OBFA odd- and branched FA, \%; DHA/EPA dinoflagellate index, 16:1/16:0 omnivory index, $(n-3) /(n-6)$ herbivory index, $U C$ unsaturation coefficient (wax ester-based omnivory index), $D W$ dry weight of one specimen
Table 3 Temora longicornis

\begin{tabular}{llll}
\hline Stages & CII & CIV & Females \\
Sampling date & 21.08 .02 & 26.08 .02 & 11.09 .02
\end{tabular}

Fatty acids

14:0

3.7

0.4

2.6

2.8

$14: 1$

0.6

$-$

15:1(n-6)

16:0

16:1(n-7)

16:1(n-5)

$16: 2(n-4)$

$16: 3(\mathrm{n}-4)$

16:4(n-1)

17:0

17:1(n-8)

18:0

18:1(n-9)

18:1(n-7)

$18: 2(\mathrm{n}-6)$

18:3(n-6)

$18: 3(n-3)$

$18: 4(\mathrm{n}-3)$

20:0

20:1(n-9)

20:1(n-7)

20:3(n-6)

20:3(n-3)

20:4(n-6)

20:4(n-3)

$20: 5(n-3)$

$22: 5(n-3)$

22:6(n-3)

Alcohols

14:0

16:0

16:1(n-7)

18:1(n-9)

18:1(n-7)

20:1(n-9)

20:1(n-7)

22:1(n-11)

SFA

MUFA

PUFA

OBFA

DHA/EPA

16:1/16:0

(n-3)/(n-6)

UC

DW $(\mu \mathrm{g})$

1.4

0.8

7.5

2.6

1.8

0.9

$-$

$-$

8.3

25.8

4.5

2.2

$-$

1.3

3.5

0.4

3.3

0.7

$-$

0.7

1.7

7.3

4.9

15.6

50.0

50.0

$-$

$-$

$-$

$-$

$-$

$-$

14.4

43.0

42.6

1.9

2.1

6.05

10.2

0.5

2.170

Relative FA content, $\%$, and main indexes. Please refer to Table 2 for the legend 
of $C$. hamatus had twofold 14:0 and 20:4(n-3) fatty acids comparing to CIVs of $T$. longicornis. The FA content of $16: 0,16: 1(n-7), 18: 1(n-9), 20: 5(n-3)$ and $22: 6(n-3)$ varied significantly in Acartia copepods of the same stages from different generations (Table 4; Fig. 4). As for Centropages and Temora, the major FAs were 18:1(n-9), and PUFA $20: 5(n-3)$ and 22:6(n-3). There was a lack of 18:4(n-3), but 16:1(n-7) and 18:0 FAs were found for females and CV copepodites, respectively (Table 4; Fig. 4). The differences in the FA content (diet) were also estimated by the PCA. The first component (season of sampling) explained about $50 \%$ of data variance; the second one, fatty acid saturation, about $30 \%$ of variance. $16: 1(n-7) / 16: 0$ ratios varied greatly for copepods of different generations but never exceed 1 .

Individual grazing and pellet production rates

Differences in grazing rate (GR) of similar stages and species measured at Station $\mathrm{K}$ and on the cruise were not significant ( $t$-test, df $=136, P=0.76$ ). Therefore, we pooled GR values by species and stages without reference to sampling area. The maximum GR expressed in organic carbon (GRC) was recorded in Temora females $\left(0.59 \pm 0.04 \mu \mathrm{g} \mathrm{C}\right.$ ind. $\left.{ }^{-1} \mathrm{~h}^{-1}\right)$, while the minimum value was observed in CII-CIII copepodites of the same species $\left(0.10 \pm 0.05 \mu \mathrm{g} \mathrm{C}\right.$ ind. $\left.^{-1} \mathrm{~h}^{-1}\right)$ (Fig 5a). GRC increased with age in all three species (ANOVA; $F=22.45$; $P<0.001)$. GRC did not depend on seston concentration expressed in carbon units (regression analysis; $R^{2}=0.09$; $F_{1,13}=1.3, P=0.27$ ).

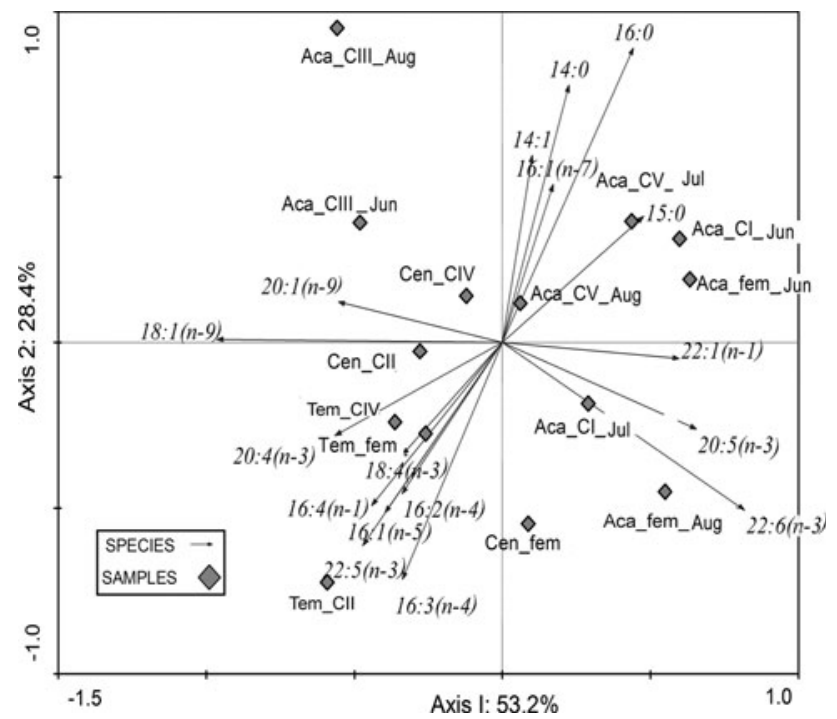

Fig. 4 Fatty acid principal component analysis. The first component is the seasonal variability of data and the second, saturation of the fatty acids analysed. Abbreviations: numbers indicate the FAs; Aca Acartia spp., Tem Temora longicornis, Cen Centropages hamatus, $\mathrm{CI}-\mathrm{CV}$, fem copepodite stages; Jun, Jul, Aug-sampling date for Acartia spp
GR of phytopigments (GRP) ranged from $0.09 \pm$ $0.04 \mathrm{ng}$ Chl. $a$ ind. $^{-1} \mathrm{~h}^{-1}$ for CII-CIII copepodites to $0.5 \pm 0.01 \mathrm{n} g$ Chl. $a$ ind. $^{-1} \mathrm{~h}^{-1}$ for females of Temora longicornis (Fig. 5b). GRP decreased in older developmental stages in Acartia and Centropages, and increased in Temora. Phytoplankton comprised up to $30 \%$ of total consumed $\mathrm{C}$ in the diet, based on PPC ratio, and GR in terms of phytopigments increased with Chl. $a$ concentration (regression analysis; $R^{2}=0.88 ; F_{1,13}=94.9, P<0.001$ ).

The rate of organic carbon excretion as faecal pellets varied from 1.3 to $6.4 \pm 0.1 \mu \mathrm{g} \mathrm{C}$ ind. ${ }^{-1}$ day $^{-1}$ (Fig. 5d). Both faecal production (FPR) and excreted carbon (FPC) were highest in Acartia spp. (ANOVA; $F=12.12$; $P<0.001$ ) (Fig. 5c, d). GRC and FPC were significantly correlated $(r=0.92 ; P<0.001 ; N=51)$ and tended to increase with the copepod developmental stage (Fig. 5a,d). FPR had an opposite tendency, and younger copepodites produced more pellets per hour than adults (Fig. 5c). Low content of phytopigments was typical for all pellets, varying from 0.9 to $19.1 \%$ of that recorded in POM. Phaeophytine content in pellets was 1.2-12.5 times higher than in POM, and 'phaeophytine/Chl. $a$ ' ratio in pellets varied from 4.2 to 41.2 . Pellets were also characterized by lower organic $\mathrm{N}$ content compared to that in ingested food. The C:N ratio for pellets varied from 6.6 to 20.5 (10.4 on average).

Zooplankton community structure with emphasis on the investigated species

During May-early June, Pseudocalanus spp. and Calanus glacialis had a significant impact on the zooplankton community both in abundance (Fig. 6a, b) and in biomass at Station K (Fig. 6c, d). During June, with increasing water temperature, these calanoids disappeared from the 0 to $10 \mathrm{~m}$ water layer (presumably they migrated deeper), and eurybiont Oithona similis became the most abundant plankter. The first individuals of Acartia spp. appeared at the beginning of July followed by Centropages hamatus and Temora longicornis. By the end of August, these species had a great impact to the zooplankton fauna, accounting for more than $50 \%$ in biomass and $20 \%$ in abundance (Fig. 6b, d). The summer community (JulyAugust) also included cyclopids Oithona similis and other holo- and meroplankton. During September, abundance of the three studied species declined. At Station K, Acartia spp. reached a density of $0.7 \times 10^{3}$ ind. $\mathrm{m}^{-3}$, while $C$. hamatus and $T$. longicornis reached $2.7 \times 10^{3}$ ind. $\mathrm{m}^{-3}$ and $1.4 \times 10^{3}$ ind. $\mathrm{m}^{-3}$, respectively (Fig. 6a). At Station D-1, the maximum total density of all studied species was lower than that at station $\mathrm{K}$, where densities ranged up to $2.7 \times 10^{3}$ ind. $\mathrm{m}^{-3}$ and $3.7 \times 10^{3}$ ind. $\mathrm{m}^{-3}$, respectively (Fig. 2d). At Station K, significant fluctuations in plankton 
Table 4 Acartia spp

\begin{tabular}{|c|c|c|c|c|c|c|c|c|}
\hline \multirow{2}{*}{$\begin{array}{l}\text { Stages } \\
\text { Sampling date }\end{array}$} & \multicolumn{2}{|l|}{ CI } & \multicolumn{2}{|l|}{ CIII } & \multicolumn{2}{|l|}{$\mathrm{CV}$} & \multicolumn{2}{|l|}{ Females } \\
\hline & 14.06 .02 & 11.07 .02 & 22.06 .02 & 21.08 .02 & 21.07 .02 & 31.08 .02 & 05.06 .02 & 01.08 .02 \\
\hline \multicolumn{9}{|l|}{ Fatty acids } \\
\hline $14: 0$ & 4.6 & 3.8 & 5.7 & 4.2 & 5.7 & 3.7 & 3.4 & 5.3 \\
\hline $14: 1$ & 0.9 & 0.8 & 1.5 & 0.7 & 0.5 & 1.3 & 0.7 & 0.8 \\
\hline $15: 0$ & 3.6 & 0.8 & 1.0 & 1.0 & 1.5 & 0.8 & 0.9 & 1.1 \\
\hline $16: 0$ & 22.4 & 14.6 & 22.8 & 17.6 & 21.7 & 17.1 & 13.5 & 20.2 \\
\hline $16: 1(n-7)$ & 3.0 & 4.4 & 7.1 & - & 4.5 & 6.8 & 3.6 & 3.5 \\
\hline $16: 2(n-4)$ & - & 0.5 & - & - & 0.6 & 0.7 & 0.8 & - \\
\hline $16: 3(n-4)$ & - & 0.6 & - & - & 0.7 & 0.5 & 0.5 & - \\
\hline $16: 4(n-1)$ & - & - & - & - & - & - & - & - \\
\hline 18:0 & 5.9 & 2.8 & 4.7 & 3.6 & 4.8 & 2.6 & 3.7 & 4.6 \\
\hline 18:1(n-9) & 11.8 & 17.4 & 29.8 & 29.0 & 13.3 & 22.2 & 14.6 & 8.9 \\
\hline $18: 1(n-7)$ & 2.8 & 2.9 & 4.1 & 2.6 & - & 4.2 & 2.3 & 3.2 \\
\hline $18: 2(n-6)$ & 4.0 & 2.3 & 1.7 & 3.7 & 2.8 & 1.5 & 2.1 & 3.1 \\
\hline $18: 3(n-6)$ & - & - & - & - & - & - & - & - \\
\hline $18: 3(n-3)$ & 1.1 & 1.7 & 0.9 & 2.0 & 1.8 & 0.8 & 1.4 & 2.3 \\
\hline $18: 4(n-3)$ & 1.1 & 3.0 & 1.4 & 5.9 & 3.7 & 1.6 & 2.6 & 4.7 \\
\hline 20:0 & 1.8 & - & 0.5 & 0.4 & 0.5 & - & - & - \\
\hline 20:1(n-9) & - & 1.1 & 3.0 & 1.7 & 2.1 & 1.7 & 1.1 & 1.8 \\
\hline $20: 1(n-7)$ & - & - & 0.6 & 0.4 & 0.4 & - & - & 0.5 \\
\hline $20: 4(n-6)$ & - & 0.5 & - & 0.4 & 0.4 & 0.3 & 0.3 & - \\
\hline $20: 4(n-3)$ & - & 2.1 & 0.9 & 3.9 & 0.6 & 0.9 & 1.7 & 1.1 \\
\hline $20: 5(n-3)$ & 11.6 & 13.6 & 5.4 & 9.9 & 12.5 & 10.2 & 10.0 & 15.0 \\
\hline $22: 5(n-3)$ & 1.1 & 0.9 & 0.6 & 0.5 & 0.8 & 0.5 & 3.9 & 1.0 \\
\hline $22: 6(n-3)$ & 24.3 & 25.3 & 8.1 & 12.5 & 21.0 & 22.2 & 32.0 & 22.8 \\
\hline \multicolumn{9}{|l|}{ Alcohols } \\
\hline $14: 0$ & 24.1 & 33.3 & 26.4 & 17.5 & 28.2 & 31.6 & 26.3 & 24.9 \\
\hline $16: 0$ & 75.9 & 66.7 & 73.6 & 82.5 & 71.8 & 68.4 & 73.7 & 75.1 \\
\hline $16: 1(n-7)$ & - & - & - & - & - & - & - & - \\
\hline $18: 1(n-9)$ & - & - & - & - & - & - & - & - \\
\hline $18: 1(\mathrm{n}-7)$ & - & - & - & - & - & - & - & - \\
\hline $20: 1(n-9)$ & - & - & - & - & - & - & - & - \\
\hline $20: 1(n-7)$ & - & - & - & - & - & - & - & - \\
\hline $22: 1(n-11)$ & - & - & - & - & - & - & - & - \\
\hline SFA & 38.3 & 22.2 & 34.7 & 26.7 & 34.3 & 24.3 & 21.8 & 31.4 \\
\hline MUFA & 18.4 & 27.2 & 46.1 & 34.4 & 20.9 & 36.4 & 22.9 & 18.6 \\
\hline PUFA & 43.2 & 50.6 & 19.2 & 38.9 & 44.9 & 39.4 & 55.3 & 50.0 \\
\hline OBFA & 26.0 & 15.4 & 23.8 & 18.6 & 23.2 & 17.9 & 14.5 & 21.2 \\
\hline DHA/EPA & 2.1 & 1.9 & 1.5 & 1.3 & 1.7 & 2.2 & 3.2 & 1.5 \\
\hline $16: 1 / 16: 0$ & 0.13 & 0.30 & 0.31 & 0.00 & 0.21 & 0.40 & 0.31 & 0.17 \\
\hline$(n-3) /(n-6)$ & 9.6 & 15.7 & 8.2 & 7.1 & 11.5 & 18.8 & 20.1 & 13.8 \\
\hline UC & 0.4 & 0.5 & 0.2 & 0.4 & 0.4 & 0.4 & 0.6 & 0.5 \\
\hline DW $(\mu \mathrm{g})$ & 1.500 & 1.625 & 2.167 & 3.000 & 4.250 & 5.000 & 5.000 & 5.000 \\
\hline
\end{tabular}

Relative FA content, \%, and main indexes. Please refer to Table 2 for the legend

density were recorded, whereas at Station D-1, plankton density increased gradually through the study period without pronounced fluctuation until mid-September
(Fig. 2d). At Station K, the seasonal dynamics of total abundance of three investigated species had three pronounced peaks in late June, July and late August, which 
Fig. 5 Feeding characteristics of investigated species. a GRC, grazing rate in terms of organic carbon, $\mu \mathrm{g} \mathrm{C}_{\text {org }}$ ind. $^{-1} \mathrm{~h}^{-1}$; b GRP, grazing rate in terms of phytopigments, ng Chl. $a$ ind. $^{-1} \mathrm{~h}^{-1}$; c FPR, faecal pellet production rate; pellet ind. $^{-1} \mathrm{~h}^{-1}$; and $\mathbf{d}$ FPC, faecal pellet production rate in terms of organic carbon, $\mu \mathrm{g} \mathrm{C}_{\text {org }}$ ind. $^{-1} \mathrm{~h}^{-1}$. Grey bars-Temora longicornis; white-

Centropages hamatus; crosshatched-Acartia spp. Each bar combines the data of one experiment ( $T$. longicornis, C. hamatus) or two experiments (Acartia spp.), 4-6 replicates each
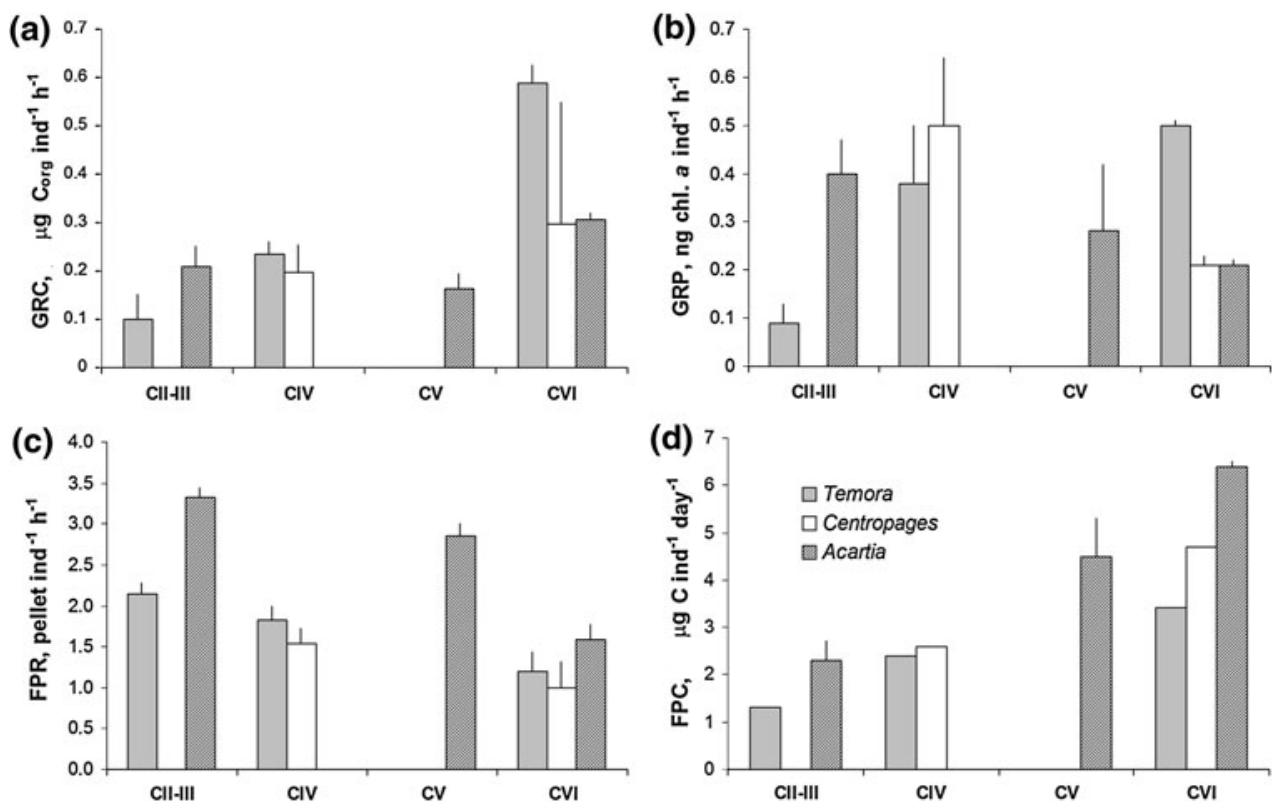

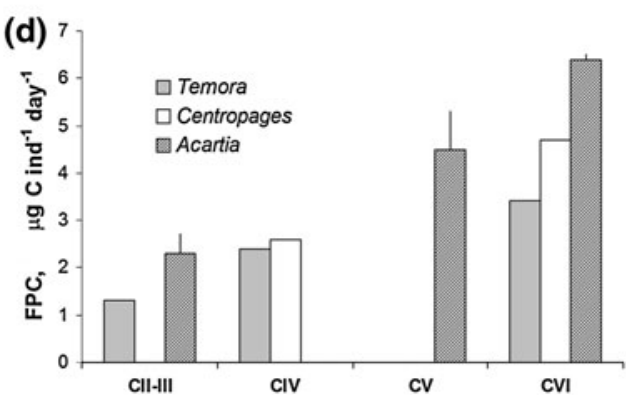

tended to follow the peaks of POC with a 1-week delay (Fig. 2c, d). There was another small peak of abundance in early June, which probably corresponds to the slight increase in POC in late May. The abundance of the studied species at Station D-1 did not follow the seasonal pattern of POC (Fig. 2c, d). The seasonal increase in copepod density in May-June at stations K and D-1 was associated with temperature increase (regression analysis, $R^{2}=0.70$; $\left.F_{1,9}=18.47 ; P<0.01\right)$. Later, from July through September, the temperature had no impact on both copepod abundance and biomass (regression analysis; $R^{2}=0.07$; $F_{1,14}=1.04 ; \quad P=0.32 ; \quad$ and $R^{2}=0.06 ; \quad F_{1,14}=1.40$; $P=0.22$; respectively). A pronounced increase in abundance was seen after the average temperature in the $0-10 \mathrm{~m}$ water layer reached $+10^{\circ} \mathrm{C}$. At stations $1-6$, abundance of the studied copepods varied from 14 to 1,237 ind. $\mathrm{m}^{-3}$ at the beginning of July (Fig. 2d). Acartia and Centropages dominated as also shown for the same period for stations D1 and $\mathrm{K}$ and Temora occurred less frequently.

Deferred population response (copepod abundance with 0,1 and 2 weeks lag) to food availability was checked through regression analyses. The start date was chosen when the abundance of copepods was $25 \%$ above the average (in most of cases, it was in mid-July, when the surface water temperature reached its seasonal maximum). Density and biomass of different species and of the three studied species together were tested. A positive influence of Chl. $a$ concentration on the 1-week lagged density was recorded (regression analysis, $R^{2}=0.43 ; F_{1,13}=9.79$; $P<0.01)$. The same was observed for POC concentration and both copepod density and biomass. When the dynamics of the three species were analysed separately, only
Centropages was dependent on both POC (density; regression analysis, $R^{2}=0.34 ; F_{1,13}=6.74 ; P<0.05$ ) and Chl. $a$ concentration (biomass; regression analysis, $\left.R^{2}=0.30 ; F_{1,13}=5.64 ; P<0.05\right)$ with 1 -week delay. Analysis of data with 2-week shift did not reveal any influence of both POC and Chl. $a$ concentration on separate species or all species together.

Throughout the summer, the age structure of the copepod populations differed significantly between stations D-1 and K. For example, mature females of Acartia spp. and Temora longicornis were relatively abundant at Station D-1 (Fig. 7a), whereas the population at the Station K consisted mainly of the immature copepodites (Fig. 7b). At Station $\mathrm{K}$, the first generation of Centropages hamatus appeared at least 5 days earlier than at Station D-1. Consequently, on June 11, only immature copepodites of this species were present at Station D-1, while females had already appeared at Station K almost a week earlier. Young copepodites of Acartia spp. and C. hamatus comprised to $96 \%$ of these species' abundance at stations 1-6 (data not shown).

Grazing and pellet contribution

Population density of studied copepod species and, thus, overall grazing activity varied greatly in different parts of the White Sea during summer. Low grazing pressure by Acartia spp. compared to the other two species was observed at Station K. Estimated grazing by Centropages hamatus was negligible in June and increased threefold from early July to late August, reaching maximal values of $570 \mathrm{mg} \mathrm{C} \mathrm{m}{ }^{-2}$ day $^{-1}$, with a subsequent decrease during September. Temora longicornis appeared abundantly by the beginning of August and, by early September, showed a 
Fig. 6 Seasonal patterns of zooplankton community structure at the station $\mathrm{K}$ (0-10 m layer): a abundance, ind. $\mathrm{m}^{-3} ; \mathbf{b}$ relative abundance, $\%$; c biomass, mg DW m ${ }^{-3}$; d relative biomass, \%. Dark grey bars-Temora longicornis; white-Centropages hamatus; light grey-Acartia spp; hatched varieties - other species
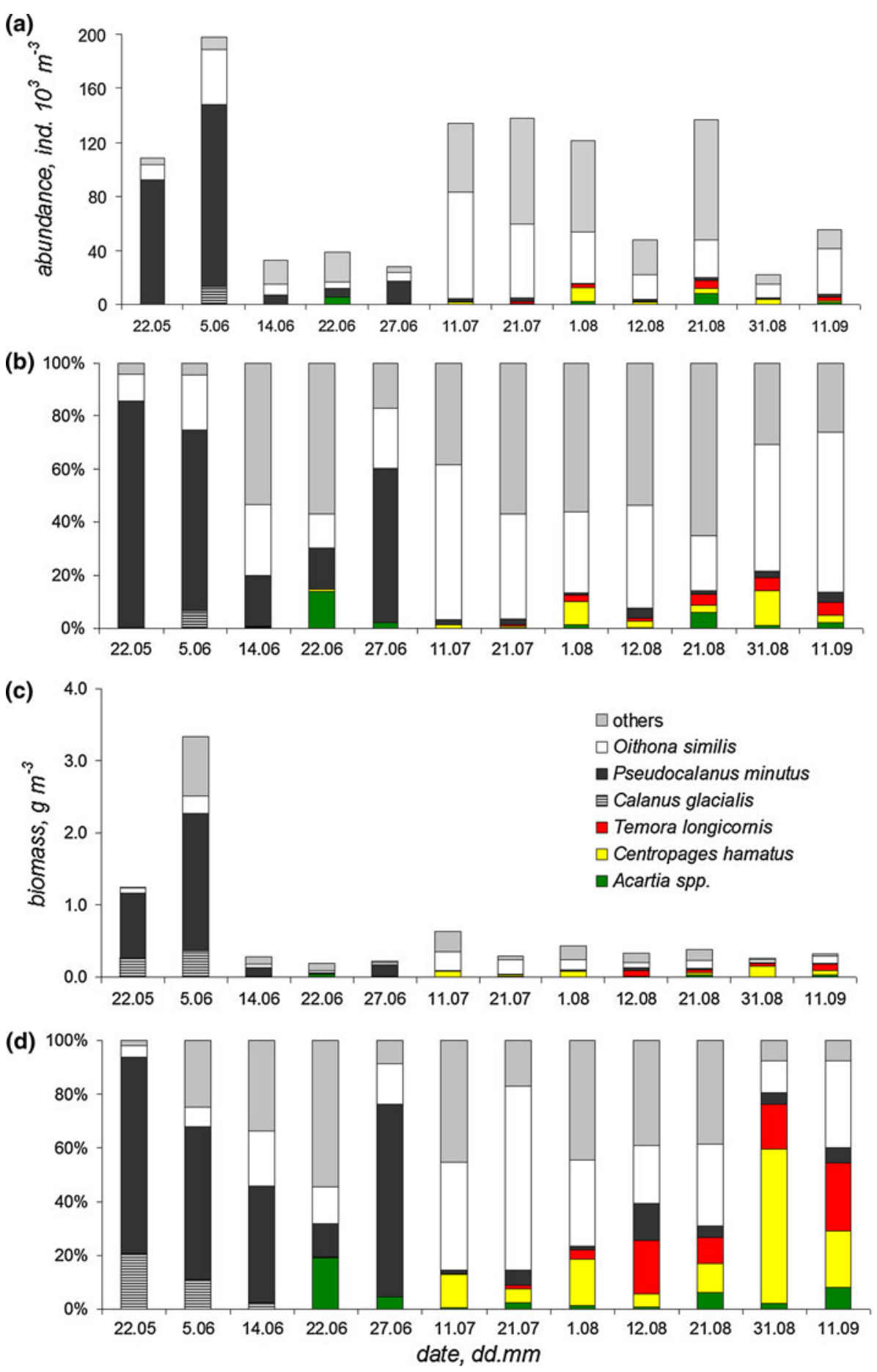

maximum grazing rate of about $300 \mathrm{mg} \mathrm{C} \mathrm{m}^{-2} \mathrm{day}^{-1}$. The pattern of species dynamics was similar at Station D-1 (data not shown). Together, the three species grazed up to 2,200 $\mathrm{mg} \mathrm{C} \mathrm{m}^{-2}$ day $^{-1}$ during September at Station K in the $0-10 \mathrm{~m}$ layer (Fig. 8a). Grazing by the studied species at Station D-1 became evident at the beginning of July and reached maximum values of about $2,000 \mathrm{mg} \mathrm{C} \mathrm{m}^{-2}$ day $^{-1}$ by the end of August (Fig. 8b). Grazing pressure dynamics had similar seasonal patterns at D-1 and $\mathrm{K}$ stations, increasing until the end of August. However, abundance of studied species and, therefore, grazing pressure in shallow waters (Station K) remained high during early September, while in a deeper area (Station D-1), a sharp decline of both parameters was observed (Fig. 8). In most cases, high copepod abundance was associated with increased grazing pressure. However, there was no significant correlation 
Fig. 7 Age structure of the three studied species.

$X$-axis-months;

$Y$-axis-relative abundance of age groups. CI-CVI

(females) - copepodite stages.

Dark grey bars-CVI (females);

white-CV-CIV copepodites;

light grey-CIII-CII

copepodites
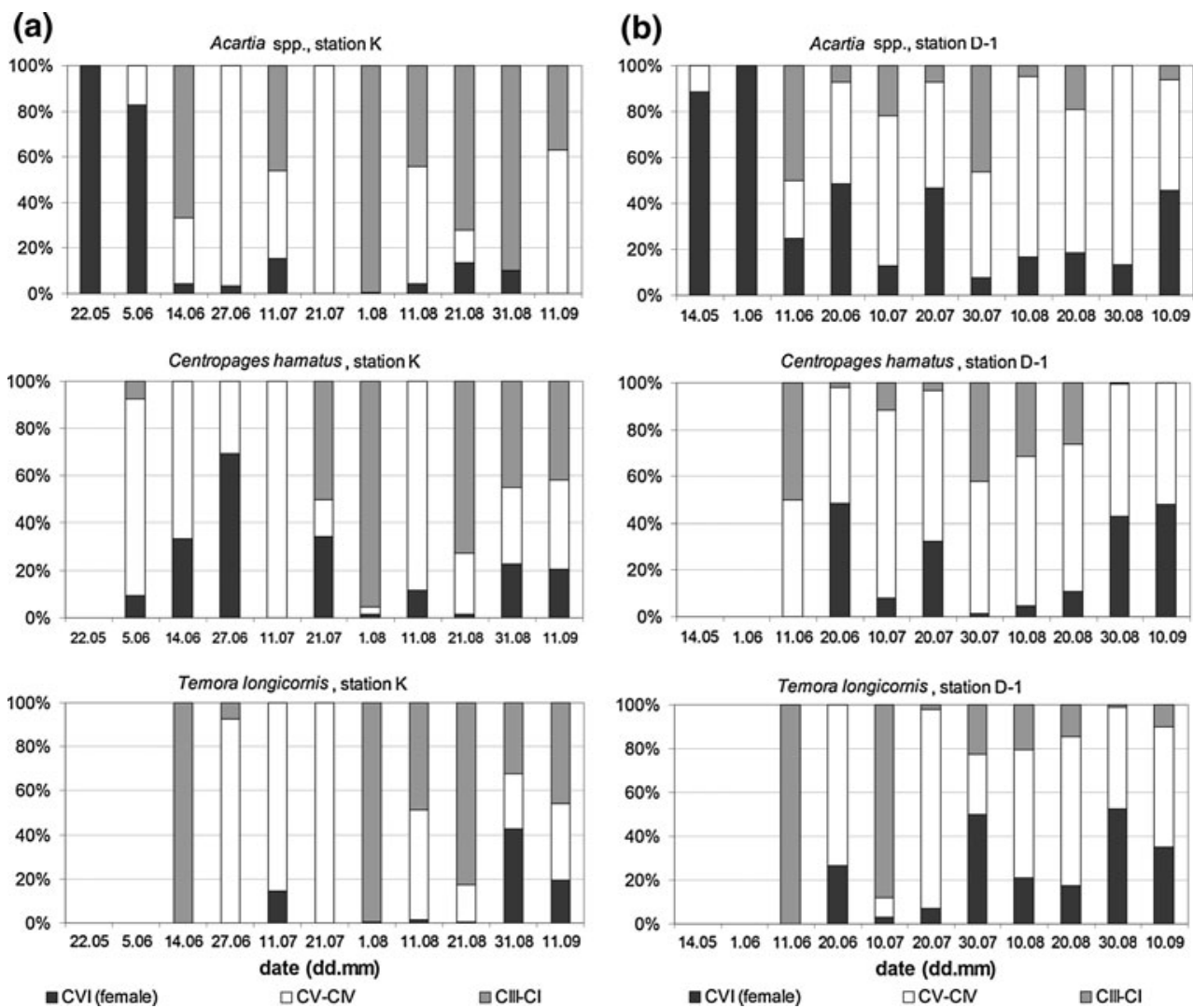

between copepod abundance and grazing pressure either for any single species (Acartia spp.: $r=0.12 ; P>0.05$; $N=22 ; C$. hamatus: $r=0.11 ; P>0.05 ; N=22 ; T$. longicornis: $r=0.09 ; P>0.05 ; N=22)$ or for the total population of these three species $(r=0.05 ; P>0.05$; $N=22$ ). Grazing pressure at the beginning of July 2002 in different parts of the White Sea (stations 1-6) by all the studied species varied by more than two orders of magnitude, from 0.4 to $68.9 \mathrm{mg} \mathrm{C} \mathrm{m}^{-3} \mathrm{day}^{-1}$. At stations $1-6$, grazing correlated positively with copepod abundance ( $r=0.99 ; P<0.01 ; N=6)$, in contrast to that observed for D-1 and $\mathrm{K}$ stations. The main reason for such a correlation may be the dominance of young copepodites of Acartia spp. and C. hamatus with almost the same feeding rates during this short time period at stations 1-6.

The relative POC grazing reached maximum values of about $50 \%$ of standing stock at the end of August at both stations. It also exhibited seasonal changes, which corresponded to copepod abundance, but did not reflect the dynamics of the potential food concentration. High copepod abundance resulted in an increase in relative POC consumption (regression analysis; $R^{2}=0.86 ; F_{1,26}=166$; $P<0.001$ ) and algal (phytopigments) consumption (regression analysis; $R^{2}=0.84 ; F_{1,26}=138 ; P<0.001$ ). Phytoplankton consumption by copepods was high at the end of summer, reaching 70-90\% of total algal biomass.
However, organic carbon incorporated by copepods from phytoplankton was less than $50 \%$ (average $35 \pm 9 \%$ ) of total ingested organic $\mathrm{C}$ and hardly reached $100 \mathrm{mg} \mathrm{C} \mathrm{m}^{-3}$ day $^{-1}$. The relative food consumption values did not depend on POC and phytopigment concentration (regression analysis; POC: $R^{2}=0.12 ; F_{1,26}=3.67$; $P=0.07 ; \quad$ phytopigments: $R^{2}=0.30 ; \quad F_{1,26}=2.63$; $P=0.12$ ). Organic carbon in pellets produced by Acartia spp., $C$. hamatus and T. longicornis varied from 0.2 to $78.3 \mathrm{mg} \mathrm{C} \mathrm{m}^{-3}$ day $^{-1}$ and did not exceed $16 \%$ of total POC concentration.

\section{Discussion}

Three copepod species, Acartia spp., Centropages hamatus and Temora longicornis, dominate in the surface water layer from late June through September in the White Sea. They play a significant role in energy transformation as the populations inhabiting $0-10 \mathrm{~m}$ water layer consume up to $50 \%$ of POC standing stock, or up to $85 \%$ of phytoplankton standing stock. The impact may be even higher taking into account that about $10 \%$ of the population live below $10 \mathrm{~m}$. These species seem to employ the same life cycle strategies; however, significant interspecific differences in temperature preferences and feeding 

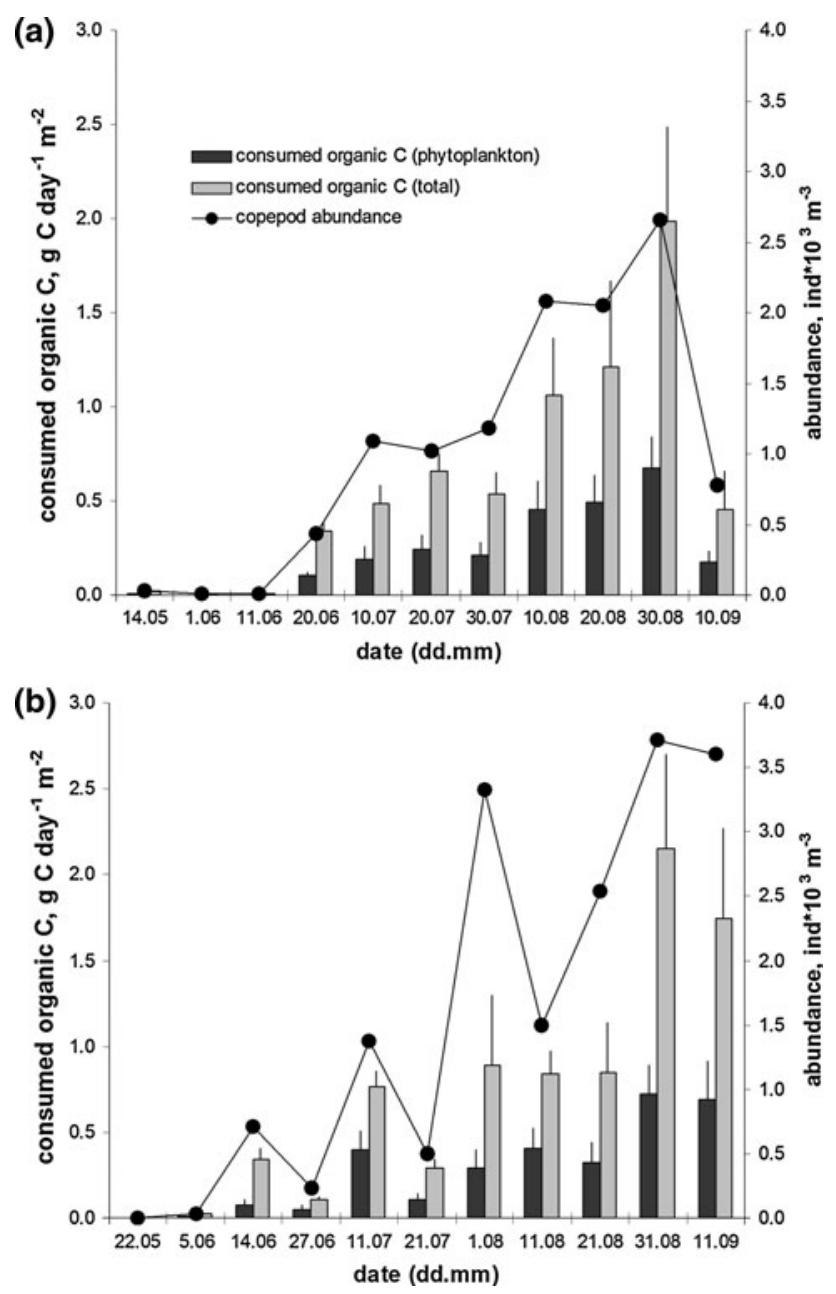

Fig. 8 Seasonal variations in POC consumption, $\mathrm{g} \mathrm{C}_{\text {org }}$ day $^{-1} \mathrm{~m}^{-2}$, by Acartia spp., Centropages hamatus and Temora longicornis at stations K a and D-1 b in 0-10 m layer. Dark grey bars-consumed organic C (phytoplankton); light grey—consumed organic C (total); dots—copepod abundance

characteristics were observed. Generally, these copepods appear to feed on the most abundant prey, including diatoms, dinoflagellates, microzooplankton and, possibly, microbial material (detritus particles), and are thus omnivorous. Acartia appears to have a wider temperature optimum than Temora and Centropages. The population of Acartia increases from late May to early June, while Temora and Centropages become more abundant in July. The latter two species tend to inhabit open areas, and Acartia is usually described as a neritic species (Berger et al. 2001). However, all three species maintain their populations successfully in the transition areas, where neritic and open-sea areas coincide.

Species of similar life cycle strategies, occupying overlapped ecological niches, such as copepods inhabiting the same water layer may be subject to strong trophic competition. Information on seasonal changes of food spectra typical for different species and developmental stages may help towards clarifying whether they compete for food. Although all three species were omnivorous and their diet overlapped, significant differences were observed in their food preferences, supported both by the PCA of the fatty acid content and food spectra analysis by counting method. Seasonal changes in the age structure of the populations may depress competition when high abundance of adults of one species coincided with high abundance of young copepodite stages of another species. Thus, their food spectra overlap less, which was supported by the FA analysis. Competition between older copepodites and adults of one species showing similar feeding preferences is depressed by the fact that they do not occur together at the same time. This relaxation of food competition may also be a result of omnivory. Omnivorous feeding has been reported for the other species of Acartia, Temora and Centropages from different areas. They feed on phytoplankton (mostly diatoms), dinoflagellates and microzooplankton (Hansen et al. 1993; Dam et al. 1994; Kleppel et al. 1996; Gasparini et al. 2000; Roman et al. 2006; Kozlowsky-Suzuki et al. 2006). Some species of Acartia genus (A. clausi, A. grani, A. tonsa) are described as herbivorous (Anraku and Omori 1963; Kleppel et al. 1991; Gasparini et al. 2000), but for A. bifilosa an omnivorous feeding was proposed by Irigoien and Castel (1995). In the Bay of Biscay, Temora longicornis does not feed on Dinophyta, while Centropages chierchiae prefers these items (Vincent and Hartmann 2001). Cotonnec et al. (2001) described omnivorous feeding for $T$. longicornis and C. hamatus from the Mediterranean based on the fatty acid analysis, when copepods preferred Cryptophyta and detritus particles. An omnivorous diet for Centropages based on the fatty acid analysis was also observed by Lavaniegos and Lopez-Cortes (1997). Jansen et al. (2006) described Acartia, Centropages and Temora species inhabiting the North Sea as omnivorous.

Omnivorous feeding is closely connected with the wellknown phenomenon of selective feeding of copepods (Päffenhofer 1988; Jansen et al. 2006; Olson et al. 2006). Selectivity may be tracked by different pathways, for example fatty acid analysis and counting methods. The copepod lipids may closely mirror available prey, such as diatoms, dinoflagellates, microzooplankton (Cripps and Hill 1998; Buhring and Christiansen 2001; Kreibich et al. 2008). Fatty acids have been successfully used as qualitative markers to trace or confirm predator-prey relationships in the marine environments (Graeve et al. 1994a; FalkPetersen et al. 2002; Dalsgaard et al. 2003). The bulk of de novo biosynthesis of fatty acids (FAs) is thought to take place among phototrophic algae at the base of the marine food web. From there, they are transferred through trophic levels and accumulated as major constituents of the lipids 
of practically all marine animals (Sargent and Falk-Petersen 1988). Long-chain and short-chain FAs and alcohols can be used to classify copepods as predominantly herbivorous or carnivorous and also to distinguish different types of phytoplankton in the diets (Albers et al. 1996). Opportunistic feeders are characterized by low levels or absence of long-chain monounsaturate FAs 20:1(n-9) and 22:1(n-11) (Graeve et al. 1994b). Thus, according to Graeve et al. (1994a, b), Kattner et al. (1994), Boyd and Newton (1995), Hagen et al. (1995), Lavaniegos and Lopez-Cortes (1997), Napolitano et al. (1997) and Cotonnec et al. (2001), the studied species ingested diatoms and dinoflagellates, while the cryptophytes (18:3(n-6), 18:3(n-3), 20:1(n-9), 20:1(n-7)) were mostly avoided by Acartia. Our analyses also suggest that detritus particles, defined by odd-branched bacterial FAs (Desvilettes et al. 1997; Colaço et al. 2007), did form part of the diet of all investigated copepods, albeit to varying extents. We surmised that the copepods did not ingest free-living bacteria, but rather detritus, bacterivorous microzooplankton, or other particles associated with bacteria (Kiørboe et al. 2002). Calanoid copepods have been shown to ingest detritus both in situ (Dagg 1993) and in vitro (Dilling et al. 1998), and their ingestion of protists is well documented (e.g., Atkinson 1996; Froneman et al. 1996). Ingestion of bacteria-associated particles occurred in all the investigated species, always in association with diatom-based herbivorous feeding. Long-chain fatty alcohols found in the present study are typical for copepods, consuming phytoplankton (Stevens et al. 2004a, b). High presence of short-chain 14:0 and 16:0 FAlc could be explained by a significant carnivorous index for the investigated animals (Tables 2, 3, 4), and this was also supported by the Utermöhl analysis. An omnivorous diet is also indicated by low $16: 1(\mathrm{n}-7) / 16: 0$ ratios and by the equal amounts of long-chain and short-chain fatty acids (Graeve et al. 1994a; Kattner et al. 1994; Napolitano et al. 1997). Low levels of long-chain monounsaturates 20:1(n-9) and 22:1(n-11) reveal the opportunistic way of feeding (Graeve et al. 1994b).

Two strategies of selective feeding are usually reported for the copepods of Acartia, Centropages and Temora. The first group of studies combines the evidence of highly selective feeding, as demonstrated for females of Centropages typicus in the New York Bight (Dagg and Grill 1980), Acartia tonsa from Florida, California, Irish Sea, Gulf Stream (Kleppel et al. 1991). Temora longicornis in the North Sea strongly depends on the food supply and has a more on detrital, animal-based diet and to a minor extent, a diatom-based diet (Kreibich et al. 2008). The food niche width for Acartia hudsonica and Temora longicornis was wide in the autumn, but decreased and overlapped completely in the early summer. These species are quite sensitive to temporal variation of the food composition (Skiver
1980). On the other hand, Acartia tonsa in Florida Bay was characterized by a diverse diet on diatoms, dinoflagellates (both auto- and heterotrophic), microzooplankton (including Protista), and selective feeding was uncommon (Kleppel and Hazzard 2000). In the North Sea estuaries, Eurytemora affinis exhibit unselective feeding by feeding on all available food items in proportion to their numerical abundance. Consequently, copepods feed mainly on detritus, a non-limiting food source in these areas. Selective feeding occurs randomly in Acartia bifilosa and A. tonsa on both phytoplankton and microzooplankton, when these organisms occur in the bloom (Tackx et al. 1995). Acartia clausi and Temora longicornis seem to behave as nonselective grazers with respect to particle size in Bedford Basin, Nova Scotia (Poulet 1978). In the White Sea, we propose high selectivity of diatoms studied throughout the season.

In the White Sea, even when the total phytoplankton concentration was high, not all the phytoplankton particles were consumed by the studied copepod species. We suggest that food may be limited by the end of the productive season and competition for available food will be high. This corresponds to the data from Cripps and Hill (1998), describing omnivorous feeding as more common in lowchlorophyll environments where copepods of the same genera usually ate the most abundant prey. In response to phytoplankton shortage, copepods may switch to alternate prey including nauplii (Tackx and Polk 1982), ciliates (Atkinson 1996), early developmental stages of other calanoids (Calbet et al. 2007) and heterotrophic dinoflagellates (Levinsen et al. 2000). Similar patterns in copepod feeding strategy were observed for the studied species in the White Sea. Thus, high selectivity in all the studied species may cause changes in the phytoplankton community. When inedible dinoflagellates prevail in the phytoplankton community in autumn, the decrease and lack of the diatoms that are the preferable food items for the copepods may limit the species populations. Food limitation significantly decreases egg production in many copepod species (McKinnon and Ayukai 1996; Kimmerer et al. 2005; Wesche et al. 2007) and thus indirectly affects the population density of the next generation (Calliari and Tiselius 2005; Halsband-Lenk 2005; Klein Breteler et al. 2005; David et al. 2006). As shown in the present study, food consumption by copepods may increase with population growth, but not necessarily, and the maximum grazing values of the whole community (in terms of organic carbon) never reached $100 \%$. However, Chl. $a$ consumption by the studied species may reach high values close to $100 \%$ of the phytoplankton standing stock, and individual grazing rates were significantly influenced by Chl. $a$ concentration. Additionally, crucial declines in species abundance correlated with food concentration 
(Chl. a), but not with temperature, as is clearly seen at Station D-1 in September (Fig. 2b, d). Moreover, the produced pellets were highly enriched with phaeophytine and were quite low in organic $\mathrm{N}$ compared to the ingested food, which suggests high assimilation rates for Chl. $a$ (Bathmann and Liebezeit 1986) and proteins (Morales 1987). The former can be supported by the data on the food spectra of these species reported above. The highest values of ingested phytoplankton were less than one-third of consumed $\mathrm{C}_{\text {org }}$ in the total diet, which may be evidence for limitation by this component. Therefore, in the White Sea, food limitation (phytoplankton component) may also indirectly affect species abundance, possibly by reducing reproduction success.

Previous studies have attributed the increase in abundance of the studied species in the White Sea to seasonal warming of the surface waters, and the decrease in abundance in autumn to a decrease in water temperatures (Golikov et al. 1989; Berger et al. 2001). However, targeted investigations and corresponding analyses were not performed as yet. The present study shows that the abundance of Acartia, Centropages and Temora in the White Sea does not necessarily correlate with surface water temperature and may be governed by food availability. The extreme variation in the abundance of these species at the beginning of July was observed in different areas of the White Sea with almost the same water temperature and salinity. Similar observations have been made for Temora species in the English Channel (Devreker et al. 2005) and for Acartia tonsa (Thompson et al. 1994). In the Baltic Sea, which is inhabited by the Centropagidae species similar to those from the White Sea, food availability is named as a factor limiting the population growth in spring, while in the autumn, the water temperature plays a significant role in Acartia spp. population dynamics (Dzierzbicka-Glowacka et al. 2009, 2010). The water temperature may also affect the reproduction success in Temora longicornis in the same region (Holste et al. 2009). The importance of both temperature and Chl. a concentration was found for Centropages species population dynamics in the North Sea, Bay of Biscay and the English Channel (Bonnet et al. 2007). The lack of food, rather than low temperature, had a significant negative effect on the Temora longicornis copepod moulting rate and lipid/protein body content (Martynova et al. 2009).

Despite similar ecological features of the species under study, the optimal temperature range varies from one species to another. Obviously Acartia has a wider temperature range than the other two, as it starts to appear and reproduce in the White Sea a month earlier. Centropages species were reported to be less adapted to pelagic life in winter than A. clausi and T. longicornis (Wesche et al. 2007). However, Temora longicornis and some Acartia species can overwinter as copepodites in the other northern European seas, even under the ice with surface temperatures close to zero (Devreker et al. 2005; Wesche et al. 2007). Therefore, other factors should be sought as limiting the studied copepods' abundance in the White Sea; water temperature could explain the spring appearance, but not all the variation in the species population dynamics.

The population dynamics is governed by environmental factors, and the role of the copepod populations in the ecosystem is consequently determined by both population dynamics and feeding characteristics of the species. Ingestion rates of the studied copepods in the White Sea varied by an order of magnitude, from 0.11 to $1.49 \mu \mathrm{g} \mathrm{C}$ ind. $^{-1}$ day $^{-1}$, and significantly increased during maturation. These values are comparable to the same parameters recorded for similar species from other seas (cf. 0.16 to $2.80 \mu \mathrm{g} \mathrm{C}$ ind. $^{-1}$ day $^{-1}$, Acartia bifilosa, A. tonsa, Temora longicornis, Centropages chierchiae; see: Irigoien and Castel 1995; Gasparini et al. 2000; Vincent and Hartmann 2001). The gut evacuation time varied from 18 to $60 \mathrm{~min}$ and fell within the wide range of $23.8-545 \mathrm{~min}$ reported for copepods from similar genera (see reviews: Corner et al. 1986; Mauchline 1998). Thus, we conclude the feeding conditions and environmental regime were favourable during our experiments, and the obtained data with high probability reflect the processes taking place in the natural environment. Pellet production and feeding rates depend on numerous factors, such as food quality and concentration (Rey et al. 1999). We assume that the prescreened seawater used in the experiments contained natural food for copepods, and hence the pellets produced in the experiments have organic carbon content and other characteristics similar to those produced by the copepods in the field. Seasonal dynamics of copepod abundance is the other important feature that is essential in assessing the contribution of these species to the ecosystem. This was low almost until the last 10 days of July, after which time these animals dominated by biomass and reached a high population density that lasted for more than a month until the beginning of September. The grazing role of these species in the White Sea is relatively high, when they graze up to $50 \%$ of organic C or up to $85 \%$ of phytoplankton standing stock and about $140 \%$ of primary production, based on ratios of production to Chl. a concentration (Berger 1995). Thus, Acartia spp., Centropages hamatus and Temora longicornis are the main consumers of phytoplankton during warm summer months, playing a central role in organic matter transformation. Obviously, the absolute values of grazing by these species may be decreased by predation, but a study of predation on the three copepod species was beyond the scope of the present paper. The absolute values obtained in the present study are somewhat higher than those reported for the same or 
related species from the other regions. For example, in the North Atlantic, Temora longicornis population may consume $21-67 \%$ of the phytoplankton production during a Phaeocystis pouchetii bloom (Hansen et al. 1993). Populations of Centropages hamatus and Centropages typicus from the same region graze 24.7 and $27.1 \%$ of phytoplankton production, respectively, or 37.6 and $78.6 \mathrm{mg} \mathrm{C} \mathrm{m}^{-2} \mathrm{day}^{-1}$ (Saiz et al. 1992). In the Yellow Sea, grazing rates of Calanus sinicus, Acartia longiremis and Centropages mcmurrichi populations were 2.9-13.5\% of POC standing stock or $77 \%$ of the daily production (Wang et al. 1998).

Faecal pellet production rate is another important characteristic of feeding, allowing calculation of feeding ratios of zooplankton and estimation of their role in biogeochemical cycle of carbon in the given area. Vertical flux of copepod faecal pellets can be estimated using pellet production rates and copepod abundance. Production of faecal pellets by copepods in the White Sea in summer ranged from 0.13 to $0.65 \mu \mathrm{g} \mathrm{C}_{\mathrm{org}}$ ind. $^{-1} \mathrm{day}^{-1}$. This is in the range of pellet production rates reported from the midAtlantic $\left(0.10-0.30 \mu \mathrm{g} \mathrm{C}_{\mathrm{org}}\right.$ ind. $^{-1}$ day $^{-1}$, Lane et al. 1994). Increase in organic carbon associated with pellets in the POC stock of the upper water column in the White Sea, calculated from faecal pellet contents, averaged up to $3.3 \%$ of the total $\mathrm{C}_{\text {org }}$ particulate matter; this value increased to about $15.3 \%$ when boreal copepods reached their highest population densities. Assuming copepods of the studied species assimilate about $50 \%$ of ingested carbon (cf. ingestion and faecal pellet production rates, present study), $70 \%$ of primary production is estimated to return to the ecosystem in pellets.

We concluded that Acartia, Centropages and Temora species play a significant role in transformation of particulate organic matter in the White Sea during the ice-free productive season. Seasonal changes in abundance of investigated species and their grazing impact depend mostly on temperature when copepods begin to appear in the early summer. Through the summer season, their abundance is governed by food availability, mostly phytoplankton. The different species and stages dominating in the same season have much in common, i.e. prefer several certain algae species. This may lead to overlap in the food spectra when the species coexist in the same period. However, the mature copepods tend to include more nonalgae components in their diet compared to younger stages. Studied species, inhabiting the same water layer $(0-10 \mathrm{~m})$, have various feeding strategies ranging from primarily herbivorous diets (young copepodites of Acartia spp.) to omnivorous with primarily carnivorous diets (mature copepods of Centropages hamatus) and omnivorous dominated by herbivorous with different preferences (others). This helps avoiding considerable overlap in feeding preferences. We also suggest the lack of available phytoplankton food and therefore switching to alternate prey (microzooplankton) for these species in the White Sea during the summer period. We suggest that the survival of copepods living in the $0-10 \mathrm{~m}$ layer during the summer season depends on 1-week difference in dominating stages of key species exploring the same feeding strategy.

Acknowledgments The DAAD (fellowship MBFOKU2001 No. A/2403), the Copernicus Foundation (grant No. ICA2-CT-200010053), Russian Foundation for Basic Researches (RFBR grants 08-0401691-a, 08-04-98843-r-sever-a, 10-04-00316-a), Otto Schmidt Labor Fellowship (grants OSL-07-11 and OSL-09-16) and State Program No. 1201051247 supported our investigations. Data on the water temperature and Chl. $a$ concentration in the 52nd cruise of RV 'Ivan Petrov' were kindly provided by Academician Alexander Lisitzin (P. P. Shirshov's Oceanology Institute, RAS, Moscow). We are grateful to Prof. Victor Berger and our colleagues from the White Sea Biological Station and from the P. P. Shirshov's Institute of Oceanology (Moscow) for their help and data courtesy, and to Prof. G. Kattner (AWI, Bremerhaven, Germany) and Dr. Janne Søreide (University Centre on Svalbard, UNIS, Longyearbyen, Norway) for useful advice. Special thanks go to Christiane Lorenzen and Helga Schwarz for their technical support of the elemental analysis at the Alfred-Wegener-Institute for Polar and Marine Research (AWI) in Bremerhaven. The authors are indebted to Dr. L. S. Barden and R. Alheit for helpful comments and linguistic improvement of the manuscript.

\section{References}

Albers CS, Kattner G, Hagen W (1996) The composition of wax esters, tryacylglycerols and phospholipids in Arctic and Antarctic copepods: evidence of energetic adaptations. Mar Chem 55:347-358

Anraku M, Omori M (1963) Preliminary survey on the relationship between the feeding habit and the structure of the mouth-parts of marine copepods. Limnol Oceanogr 8:116-126

Atkinson A (1996) Subantarctic copepods in an oceanic, low chlorophyll environment: ciliate predation, food selectivity and impact on prey population. Mar Ecol Prog Ser 130:85-86

Bathmann U, Liebezeit G (1986) Chlorophyll in copepod faecal pellets: changes in pellet numbers and pigment content during a declining Baltic spring bloom. Mar Ecol 7:59-73

Berger VJa (ed) (1995) White Sea. Biological resources and problems of their rational exploitations. Explorations of the faunas of the seas 42(50). Zoological Institute RAS Publ. St. Petersburg (in Russian)

Berger VJa (2007) Production potential of the White Sea. Explorations of the faunas of the seas, 60(68). Zoological Institute RAS Publ. St. Petersburg (in Russian)

Berger V, Dahle S, Galaktionov K, Kosobokova X, Naumov A, Rat'kova T, Savinov V, Savinova T (2001) White Sea. Ecology and environment. Derzavets Publisher, St. Petersburg-Troms $\varnothing$

Berger VJa, Naumov AD, Usov N, Zubaha M, Smolyar I, Tatusko R, Levitus S (2003) 36-year time series (1963-1998) of zooplankton, salinity and temperature in the White Sea, NOAA Atlas NESDIS 57, $362 \mathrm{p}$

Berggreen U, Hansen B, Kiørboe T (1988) Food size spectra, ingestion and growth of the copepod Acartia tonsa during development: implication for determination of copepod production. Mar Biol 99:341-352

Bobrov JA, Maximova MP, Savinov VM (1995) Primary production of phytoplankton. White Sea. Explorations of the faunas of the seas, 42(50). Zoological Institute RAS Publ. St. Petersburg 
Bonnet D, Harris R, Lopez-Urrutia A, Halsband-Lenk C, Greve W, Valdes L, Hirche H-J, Engel M, Alvarez-Ossorio MT, Wiltshire K (2007) Comparative seasonal dynamics of Centropages typicus at seven coastal monitoring stations in the North Sea, English Channel and Bay of Biscay. Prog Oceanogr 72(2-3): 233-248

Boyd P, Newton P (1995) Evidence of the potential influence of planktonic community structure on the interannual variability of particulate organic carbon flux. Deep Sea Res 42:619-639

Breteler WCMK, Schogt N, Rampen S (2005) Effect of diatom nutrient limitation on copepod development: role of essential lipids. Mar Ecol Prog Ser 291:125-133

Buhring SI, Christiansen B (2001) Lipids in selected abyssal benthopelagic animals: links to the epipelagic zone? Prog Oceanogr 50:369-382

Calbet A, Carlotti F, Gaudy R (2007) The feeding ecology of the copepod Centropages typicus (Kröyer). Prog Oceanogr 72:137-150

Calliari D, Tiselius P (2005) Feeding and reproduction in a small Calanoid copepod: Acartia clausi can compensate quality with quantity. Mar Ecol Prog Ser 298:241-250

Carmack E, Wassmann P (2006) Food webs and physical-biological coupling on pan-arctic shelves: unifying concepts and comprehensive perspectives. Prog Oceanogr 71:446-477

Colaço A, Desbruyé D, Guezennec J (2007) Polar lipid fatty acids as indicators of trophic associations in a deep-sea vent system community. Mar Ecol 28:15-24

Corner EDS, O'Hara SCM, Neal AC, Eglinton G (1986) Copepod faecal pellets and the vertical flux of biolipids. In: Corner EDS, O'Hara SCM (eds) The biological chemistry of marine copepods. Clarendon Press, Oxford, pp 260-321

Cotonnec G, Brunet C, Sautour B, Thoumelin G (2001) Nutritive value and selection of food particles by copepods during a spring bloom of Phaeocystis sp. in the English Channel, as determined by pigment and fatty acid analyses. J Plank Res 23:693-703

Cripps GC, Hill HJ (1998) Changes in lipid composition of copepods and Euphausia superba associated with diet and environmental conditions in the marginal ice zone, Bellingshausen Sea, Antarctica. Deep Sea Res I 45:1357-1381

Dagg M (1993) Sinking particles as a possible source of nutrition for the large calanoid copepod Neocalanus cristatus in the subarctic Pacific Ocean. Deep Sea Res I 40:1431-1445

Dagg M, Grill DW (1980) Natural feeding rates of Centropages typicus females in the New York Bight. Limnol Oceanogr 25:597-609

Dalsgaard J, St John M, Kattner G, Müller-Navarra D, Hagen W (2003) Fatty acid trophic markers in the pelagic marine environment. Adv Mar Biol 46:225-340

Dam HG, Peterson WT, Bellantoni DC (1994) Seasonal feeding and fecundity of the calanoid copepod Acartia tonsa in long Island sound: is omnivory important to egg production? Hydrobiologia 292(293):191-199

David V, Sautour B, Galois R, Chardy P (2006) The paradox high zooplankton biomass-low vegetal particulate organic matter in high turbidity zones: what way for energy transfer? J Exp Mar Biol Ecol 333:202-218

Desvilettes CH, Bourdier G, Amblard CH, Barth B (1997) Use of fatty acids for the assessment of zooplankton grazing on bacteria, protozoans and microalgae. Freshw Biol 38:629-637

Devreker D, Souissi S, Seuront L (2005) Effects of chlorophyll concentration and temperature variation on the reproduction and survival of Temora longicornis (Copepoda, Calanoida) in the Eastern English Channel. J Exp Mar Biol Ecol 318:145-162

Dilling L, Wilson J, Steinberg D, Alldredge A (1998) Feeding by euphausiid Euphausia pacifica and the copepod Calanus pacificus on marine snow. Mar Ecol Prog Ser 170:189-201
Dzierzbicka-Głowacka L, Lemieszek L, Żmijewska MI (2009) Parameterisation of a population model for Acartia spp. in the southern Baltic Sea Part 1. Development time. Oceanologia 51(2):165-184

Dzierzbicka-Glowacka L, Żmijewska IM, Mudrak S, Jakacki J, Lemieszek A (2010) Population modeling of Acartia spp. in a water column ecosystem model for the Southern Baltic Sea. Biogeosci Discuss 7:55-82

Evans CA, O'Reilly JE, Thomas JP (1987) A handbook for the measurement of chlorophyll $a$ and primary production. Biological Investigations of Marine Antarctic Systems and Stocks (BIOMASS). Texas A\&M University College Station, Texas

Falk-Petersen S, Sargent JR, Tande K (1987) Lipid composition of zooplankton in relation to the Sub-Arctic food web. Polar Biol $8: 115-120$

Falk-Petersen S, Dahl TM, Scott CL, Sargent JR, Gulliksen B, Kwasniewski S, Hop H, Millar RM (2002) Lipid biomarkers and trophic linkages between ctenophores and copepods in Svalbard waters. Mar Ecol Prog Ser 227:187-194

Folch J, Lees M, Sloane-Stanley GH (1957) A simple method for isolating total lipids from animal tissues. J Biol Chem 226: 497-509

Froneman PW, Pakhomov EA, Perissinotto R, McQuaid CD (1996) Role of microplankton in the diet and daily ration of Antarctic zooplankton species during austral summer. Mar Ecol Prog Ser 143:15-23

Frost BW (1972) Effect of size and concentration of food on the feeding behavior of marine planktonic copepod Calanus pacificus. Limnol Oceanogr 17:805-816

Gasparini S, Daro MH, Antajan E, Tackx M, Rousseau V, Parent JY, Lancelot C (2000) Mesozooplankton grazing during the Phaeocystis globosa bloom in the Southern Bight of the North Sea. J Sea Res 43:345-356

Gifford DJ, Fessenden ML, Garrahan PR, Martin E (1995) Grazing by microzooplankton and mesozooplankton in high-latitude North Atlantic Ocean: spring versus summer dynamics. J Geophys Res 100:6665-6675

Golikov AN, Babkov AI, Prygunkova RV (1989) On the question of structure and distribution patterns of the White Sea ecosystems due to the geomorphology and hydrology. Proc Zool Inst AN USSR, Leningrad, vol. 203, 4-13 (in Russian)

Graeve M, Hagen W, Kattner G (1994a) Herbivorous or omnivorous? on the significance of lipid composition as trophic markers in Antarctic copepods. Deep Sea Res I 41:915-924

Graeve M, Hagen W, Kattner G (1994b) Diet-induced changes in the fatty acids composition of Arctic herbivorous copepods: experimental evidence of trophic markers. J Exp Mar Biol Ecol 182:97-110

Hagen W (1999) Reproductive strategies and energetic adaptations of polar zooplankton. Invertebrate Reprod Dev 36:25-34

Hagen W, Kattner G, Graeve M (1995) On the lipid biochemistry of polar copepods: compositional differences in the Antarctic calanoids Euchaeta antactica and Euchirella rostromagna. Mar Biol 123:451-457

Halsband-Lenk C (2005) Metridia pacifica in Dabob Bay, Washington: the diatom effect and the discrepancy between high abundance and low egg production rates. Prog Oceanogr 67:422-441

Hansen FC, Breteler WCMK, Reckermann M, Riegman R (1993) Phaeocystis blooming enhanced by copepod predation on protozoa: evidence from incubation experiments. Mar Ecol Prog Ser 102:51-57

Harris RP, Lenz J, Wiebe PH, Huntley ME, Skjoldal HR (2000) Zooplankton methodological manual. Academic Press, NY

Holste L, St John MA, Peck MA (2009) The effects of temperature and salinity on reproductive success of Temora longicornis in the Baltic Sea: a copepod coping with a tough situation. Mar Biol 156:527-540 
Irigoien X, Castel J (1995) Feeding rates and productivity of the copepod Acartia bifilosa in a highly turbid estuary; The Gironde (SW France). Hydrobiologia 311:115-125

Jansen S, Riser CW, Wassmann P, Bathmann U (2006) Copepod feeding behaviour and egg production during a dinoflagellate bloom in the North Sea. Harmful Algae 5:102-112

Kattner G, Fricke HSG (1986) Simple gas-liquid chromatographic method for the simultaneous determination of fatty acids and alcohols in wax esters of marine organisms. J Chromatogr 361:263-268

Kattner G, Graeve M, Hagen W (1994) Ontogenetic and seasonal changes in fatty acid/alcohol compositions of the dominant Antarctic copepod Calanus propincuus, Calanoides acutus and Rhincalanus gigas. Mar Biol 118:637-644

Kimmerer WJ, Ferm N, Nicolini MH, Peñalva C (2005) Chronic food limitation of egg production in populations of copepods of the genus Acartia in the San Francisco Estuary. Estuar Coasts 28(4):541-550

Kiørboe T, Grossart H-P, Ploug H, Tang KW (2002) Mechanisms and rates of bacterial colonization of sinking aggregates. Appl Environ Microbiol 68(8):3996-4006

Kleppel GS, Holliday DV, Pieper RE (1991) Trophic interactions between copepods and microplankton: a question about the role of diatoms. Limnol Oceanogr 36:172-178

Kleppel GS, Burkart CA, Carter K, Tomas C (1996) Diets of calanoid copepods on the West Florida continental shelf: Relationships between food concentration, food composition and feeding activity. Mar Biol 127:209-217

Kleppel GS, Hazzard SE (2000) Diet and egg production of the copepod Acartia tonsa in Florida Bay. II. Role of nutritional environment. Mar Biol 137:111-121

Kosobokova KN (1999) The reproductive cycle and life history of the Arctic copepod Calanus glacialis in the White Sea. Polar Biol 22:254-263

Kozlowsky-Suzuki B, Carlsson P, Ruhl A, Graneli E (2006) Food selectivity and grazing impact on toxic Dinophysis spp. by copepods feeding on natural plankton assemblages. Harmful Algae 5:57-68

Kreibich T, Saborowski R, Hagen W, Niehoff B (2008) Short-term variation of nutritive and metabolic parameters in Temora longicornis females (Crustacea, Copepoda) as a response to diet shift and starvation. Helgol Mar Res 62(3):241-249

Lane PVZ, Smith SL, Urban JL, Biscaye PE (1994) Carbon flux and recycling associated with zooplanktonic faecal pellets on the shelf of the middle Atlantic Bight. Deep Sea Res 41:437-457

Lavaniegos BE, Lopez-Cortes D (1997) Fatty acid composition and community structure of plankton from San Lorenzo Channel, Gulf of California. Estuar Coast Shelf Sci 45:845-854

Levinsen H, Turner T, Nielsen TG, Hansen BW (2000) On the trophic coupling between protists and copepods in Arctic marine ecosystems. Mar Ecol Prog Ser 204:65-77

Martynova DM (2003) Copepod faecal pellets in the White Sea: experimental and in situ studies. Oceanology 43:S123-S133

Martynova DM (2005) Feeding of the mass species of the White Sea copepods. Oceanology 45(2):249-255

Martynova DM, Graeve M, Bathmann UV (2009) Adaptation strategies of copepods (superfam. Centropagoidea) in the White Sea $(66$ N). Polar Biol 32:133-146

Mauchline J (1998) Biology of calanoid copepods. Advances in marine biology. The Scottish Association for Marine Science, UK

McKinnon AD, Ayukai T (1996) Copepod egg production and food resources in Exmouth Gulf, Western Australia. Mar Freshw Res 47(4):595-603

Morales CE (1987) Carbon and nitrogen content of copepod faecal pellets: effect of food concentration and feeding behavior. Mar Ecol Prog Ser 36:107-114
Mousseau L, Breteler WCMK, Legendre L, Dauchez S, Tamigneaux E, Tremblay J-E, Ingram RG (2001) Assessing the trophic pathways that dominate planktonic food webs: an approach based on simple ecological ratios. J Plankton Res 23:765-777

Napolitano GE, Pollero RJ, Gayoso AM, McDonald BA, Thompson RJ (1997) Fatty acids as trophic markers of phytoplankton bloom in the Bahia Blanca Estuary (Buenos Aires, Argentina) and in Trinity Bay (Newfoundland, Canada). Biochem Syst Ecol 25:739-755

Olli K, Wassmann P, Reigstad M, Ratkova TN, Arashkevich E, Pasternak A, Matrai PA, Knulst J, Tranvik L, Klais R, Jacobsen A (2007) The fate of production in the central Arctic Oceantop-down regulation by zooplankton expatriates? Prog Oceanogr 72:84-113

Olson MB, Lessard EJ, Wong CHJ, Bernhardt MJ (2006) Copepod feeding selectivity on microplankton, including the toxigenic diatoms Pseudonitzschia spp., in the coastal Pacific Northwest. Mar Ecol Prog Ser 326:207-220

Päffenhofer G-A (1988) Feeding rates and behavior of zooplankton. Bull Mar Sci 43:430-445

Parsons TR, Maita Y, Lalli CM (1984) A manual of chemical and biological methods for seawater analysis. Pergamon Press, NY

Pasternak AF (1995) Gut content and diel feeding rhythm in dominant copepods in the ice-covered Weddell Sea, March 1992. Polar Biol 15:583-586

Pertsova NM, Kosobokova KN (2003) Zooplankton of the White Sea: features of the composition and structure, seasonal dynamics, and the contribution to the formation of matter fluxes. Oceanology 43:S108-S122

Poulet SA (1978) Comparison between five coexisting species of marine copepods feeding on naturally occurring particulate matter. Limnol Oceanogr 23:1126-1143

Prygunkova RV (1974) Some features of zooplankton seasonal changes in Chupa Inlet, the White Sea (Nekotorye osobennosti sezonnogo razvitiya zooplanktona guby Chupa Belogo morya). Seasonal changes in the White and Barents Seas (Sezonnye yavleniya v zhizni Belogo i Barentseva morey). Studies on Sea Fauna (Issledovaniya Fauny Morey), Leningrad, vol. 13 (21), 4-55 (in Russian)

Rey C, Carlotti F, Tande K, Hygum BH (1999) Egg and faecal pellet production of Calanus finmarchicus females from controlled mesocosms and in situ populations: Influence of age and feeding history. Mar Ecol Prog Ser 188:133-148

Roman MR, Reaugh ML, Zhang XS (2006) Ingestion of the dinoflagellate, Pfiesteria piscicida, by the calanoid copepod, Acartia tonsa. Harmful Algae 5:435-441

Romankevich EA, Vetrov AA (2001) Carbon cycle in the Russian Arctic Seas. Moscow: Nauka (in Russian)

Saiz E, Rodriguez V, Alcaraz M (1992) Spatial distribution and feeding rates of Centropages typicus in relation to frontal hydrographic structures in the Catalan Sea (Western Mediterranean). Mar Biol 112(1):49-56

Sargent JR, Falk-Petersen S (1988) The lipid biochemistry of calanoid copepods. Hydrobiologia 167(168):101-114

Skiver J (1980) Seasonal resource partitioning patterns of marine calanoid copepods: species interactions. J Exp Mar Biol Ecol 44:229-245

Stevens CJ, Deibel D, Parrish CC (2004a) Copepod omnivory in the North Water Polynya (Baffin Bay) during autumn: spatial patterns in lipid composition. Deep Sea Res I 51:1637-1658

Stevens CJ, Deibel D, Parrish CC (2004b) Species-specific differences in lipid composition and omnivory indices in Arctic copepods collected in deep water during autumn (North Water Polynya). Mar Biol 144:905-915

Svensen C, Nejsgaard JC (2003) Sedimentation of copepod faecal pellets determined by cyclopoids? Evidence from enclosed ecosystems. J Plankton Res 25:917-926 
Tackx M, Polk P (1982) Feeding of Acartia tonsa Dana (Copepoda, Calanoida): predation on nauplii of Canuella perplexa $\mathrm{T}$. et A. Scott (Copepoda, Harpacticoida) in the sluice-dock at Ostend. Hydrobiologia 94(2):131-133

Tackx M, Irigoien X, Castel J, Zhu M-Y, Daro N, Zhang X, Nijs J (1995) Copepod feeding in the Westerschelde and the Gironde. Hydrobiologia 311:71-83

Tande K, Henderson RJ (1988) Lipid composition of copepodite stages and adult females of Calanus glacialis in Arctic waters of the Barents Sea. Polar Biol 8:333-339

Thompson AM, Durbin EG, Durbin AG (1994) Seasonal changes in maximum ingestion rate of Acartia tonsa in Narragansett Bay, Rhode Island, USA. Mar Ecol Prog Ser 108:91-105
Usov NV, Zubakha MA (2004) Temperature optimums of the White Sea zooplankton. Biologya morya Russ J Mar Biol 30:34-43

Utermöhl H (1958) Zur Vervollkommnung der quantitativen Phytoplankton-Methodik. Mitteilungen Int Vereinigung Theoretische und Angew Limnol 9:1-38

Vincent D, Hartmann HJ (2001) Contribution of ciliated microprotozoans and dinoflagellates to the diet of three copepod species in the Bay of Biscay. Hydrobiologia 443:193-204

Wang R, Li C, Wang K, Zhang W (1998) Feeding activities of zooplankton in the Bohai Sea. Fisheries Oceanogr 7(3/4):265-271

Wesche A, Wiltshire KH, Hirche HJ (2007) Overwintering strategies of dominant calanoid copepods in the German Bight, southern North Sea. Mar Biol 151(4):1309-1320 